\title{
Local Gambling Preferences and Corporate Innovative Success
}

\author{
Yangyang Chen, Edward J. Podolski, S. Ghon Rhee, \\ and Madhu Veeraraghavan*
}

\begin{abstract}
This paper examines the role of local attitudes toward gambling on corporate innovative activity. Using a county's Catholics-to-Protestants ratio as a proxy for local gambling preferences, we find that firms located in gambling-prone areas tend to undertake riskier projects, spend more on innovation, and experience greater innovative output. We contrast the local gambling effect with chief executive officer (CEO) overconfidence, another behavioral effect reported to influence innovation. We find that local gambling preferences are a stronger determinant of innovative activity, with CEO overconfidence being more relevant to innovation in areas where gambling attitudes are strong.
\end{abstract}

\section{Introduction}

The fact that locally held attitudes influence corporate decisions is well documented in the literature (e.g., Hilary and Hui (2009), Kumar, Page, and Spalt (2011), Callen and Fang (2014)). Ultimately, corporations are not detached from their local environment, but interact with their surroundings through local employees, local customers, and local suppliers. Given the potential importance of attitudes held by local residents for corporate outcomes, we study the effects that

\footnotetext{
*Chen, yangyang.chen@monash.edu, Department of Banking and Finance, Monash University, W1016, Building 11, Monash University Clayton Campus, VIC 3800, Australia; Podolski, e.podolskiboczar@latrobe.edu.au, Department of Finance, La Trobe University, Martin Building 470, La Trobe University Melbourne Campus, VIC 3086, Australia; Rhee, rheesg@ hawaii.edu, Shidler College of Business, University of Hawaii, 2404 Maile Way, Honolulu, HI 96822 and Monash University; Veeraraghavan, madhuveeraraghavan@tapmi.edu.in, Finance Area, T. A. Pai Management Institute, PB No 9, Manipal, Karnataka 576104, India. We thank Christine Brown, Rosita Chang, Xin Chang, Philip Gray, Jarrad Harford (the editor), Francis In, Boochun Jung, Jay Heon Jung, Jun-Koo Kang, Joon-Ho Kim, Alexander Ljungqvist, Kwang Woo Park, Choong-Yuel Yoo, and seminar participants at Monash University, Korea Advanced Institute of Science and Technology, and National Cheng Kung University for helpful comments and suggestions. We are especially grateful to an anonymous referee for the insightful comments and suggestions that have significantly improved the paper. We are also grateful to David Hirshleifer, Angie Low, and Siew Hong Teoh for providing the press-based measure of CEO overconfidence. We thank Kuankuan Wang for excellent research assistance. Rhee is grateful for a summer research grant from the Shidler College of Business.
} 
these attitudes have on corporate innovation. Recent papers identify numerous factors that influence innovative activity. They include: managerial overconfidence (Galasso and Simcoe (2011), Hirshleifer, Low, and Teoh (2012)), institutional ownership (Aghion, Van Reenen, and Zingales (2013)), corporate governance (Sapra, Subramanian, and Subramanian (2014)), analysts following (He and Tian (2013)), stock liquidity (Fang, Tian, and Tice (2014)), banking deregulation (Chava, Oettl, Subramanian, and Subramanian (2013)), accounting conservatism (Chang, Hilary, Kang, and Zhang (2013)), nonexecutive employee stock options (Chang, Fu, Low, and Zhang (2014)), and so on. Nevertheless, the existing literature does not explain the apparent geographical disparity in innovative activity across the United States, as illustrated in Figure 1, which shows wide variation of research and development (R\&D) expenditure per gross domestic product (GDP) at the state level. ${ }^{1}$ Motivated by a growing literature on the geographical variation in social gambling attitudes across the United States (Kumar (2009), Kumar et al. (2011)), we examine the relation between locally held attitudes toward gambling and innovative activity.

\section{FIGURE 1}

\section{Geographical Distribution of R\&D}

Figure 1 illustrates the geographical distribution of R\&D spending scaled by the GDP of each state. The data are obtained from the National Science Foundation and are based on 2007 data. For each state, we compile the total corporate and government R\&D spending in 2007 and scale it by state GDP in the same year.

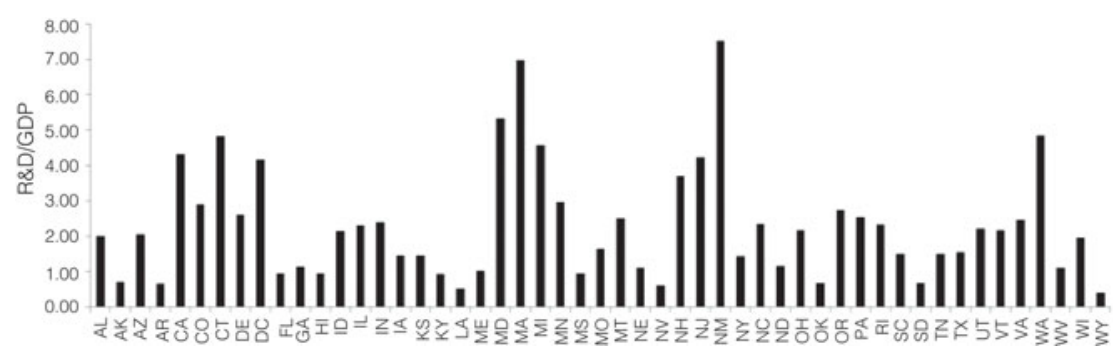

Gambling preferences are naturally relevant to innovative activity, with innovation possessing many lottery-like features. Investment in innovation is risky as well as idiosyncratic, and it involves a high probability of failure (Holmstrom (1989)). At the same time, when successful, innovation offers large payoffs in the form of enhanced competitiveness and improvements in the overall reputation and prestige of the firm. Consequently, innovative activity is more likely to be observed in those areas where people have a natural tendency to gamble. A quick glance at the per capita lottery sales in the five most R\&D-intensive states and the five least R\&D-intensive states reveals that states where gambling is more prevalent spend considerably more on innovation (Figure 2 ).

We make a simple and intuitive argument. Firms located in areas where local residents are prone to gambling are more likely to gamble on innovation. Although innovation is necessary for firms to maintain (or develop) a competitive

\footnotetext{
${ }^{1}$ Data by the National Science Foundation reveal a significant variation in R\&D spending among states, even after scaling for economic development.
} 
FIGURE 2

R\&D Spending and State Lotteries

Figure 2 illustrates the per capita lottery sales in the five states that spend the most (least) on R\&D (scaled by state GDP). Data on state-level R\&D spending per GDP are obtained from the National Science Foundation for the year 2007. The state-level per capita lottery sales are based on the same year.

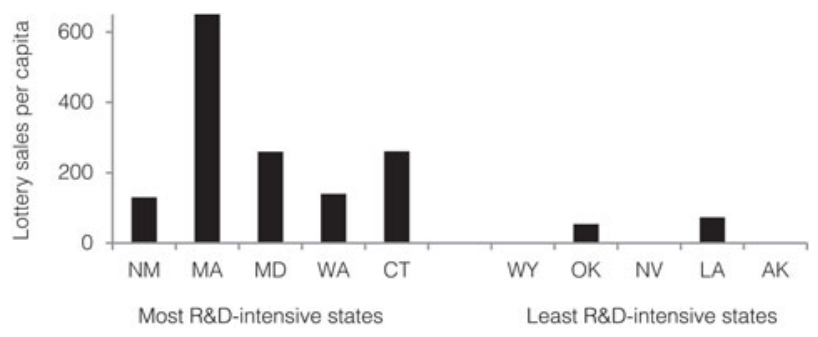

edge, a number of features of innovation make it unappealing for rational managers and investors. These factors include the long-term nature of research projects, the high likelihood of failure, and large information asymmetry between insiders and outside investors. Classical career concern models in the spirit of Narayanan (1985) leave little room for rational managers to invest in innovation, even if such investments are productive to the firm in the long run. Similarly, He and Tian (2013) show that short-termism in capital markets discourages firms from pursuing innovative projects.

We argue that a gambling-prone culture inside a firm alleviates some of these problems. For example, firms influenced by a pro-gambling culture are more likely to offer incentive contracts that encourage investment in risky projects (Manso (2011), Chang et al. (2014)), and managers influenced by gambling preferences are more likely to risk the wrath of investors in pursuit of the high potential gains (to the firm and the manager) associated with innovation (Holmstrom (1989), Asker, Farre-Mensa, and Ljungqvist (2011), and He and Tian (2013)). In this respect, our argument is similar to Hirshleifer et al. (2012), who argue that managerial overconfidence is conducive to innovative activity by overcoming the natural disincentives associated with innovation.

The impact that social gambling preferences have on innovative outcomes is less clear. If gambling attitudes overcome underinvestment in innovation and lead firms to undertake worthwhile projects, then we should see higher innovative output in areas with a higher propensity to gamble. In addition, since local gambling attitudes affect the culture of the entire organization, rather than simply the behavioral patterns of the top executives within the firm, employees at all levels of the organization are likely to take higher levels of risk when pursuing innovative projects. Since risk taking is necessary when developing new and creative inventions, firms in gambling-prone areas should achieve higher innovative output even after accounting for R\&D expenditure. Anecdotally, Apple Inc. is evidence that a risk-taking culture produces very unique and innovative products.

On the other hand, firms predisposed to gamble are more likely to invest resources recklessly and inefficiently. As a consequence, firms influenced by a locally held appetite for gambling may experience no increase in innovative output despite spending more on R\&D. Aghion et al. (2013) highlight that a dollar 
invested in $\mathrm{R} \& \mathrm{D}$ does not always result in higher research output. They further show that strong oversight of managers is necessary to ensure that R\&D spending is productive. Due to these conflicting views, we do not hypothesize the effect that gambling preferences have on innovative output.

Consistent with prior literature (Kumar (2009), Kumar et al. (2011)), we measure the gambling preferences of a local area (defined as a geographical county area) using the Catholics-to-Protestants ratio (CP ratio). ${ }^{2}$ The level of a company's investment in innovation is measured as $\mathrm{R} \& \mathrm{D}$ expenditure scaled by book assets. Measuring innovative output is more difficult, given that the primary output of R\&D investment is intangible and in the form of the firm's knowledge base, from which profits in future years will be generated. Since firms can protect this intellectual property by applying to the U.S. Patent and Trademark Office to have their invention patented (subject to proving that the invention is novel, nontrivial, and has commercial application), patent data from the National Bureau of Economic Research (NBER) are used to construct our measures of innovative output.

The first measure of innovative output is the number of patents applied for during the year from the U.S. Patent and Trademark Office. Firms that apply for a greater number of patents are regarded as having more inventions. Because patents differ significantly in their impact and importance, the second measure of innovative output is the total number of citations received per patent applied for. The idea behind the second proxy of innovative output is that more significant inventions will receive a greater number of citations than less groundbreaking inventions. The sample spans the period 1980 to 2006. The cutoff year is dictated by data availability from the NBER patent database.

We find that firms headquartered in counties with higher $\mathrm{CP}$ ratios (i.e., a higher propensity to gamble) undertake riskier projects and spend more on innovation. These firms also achieve higher innovative output, as measured by the volume of patents applied for and the citations that these patents receive. Our results are robust to a number of alternative model specifications. Furthermore, we show that the results are not driven by reverse causality, and we exhaustively address the omitted variable bias.

The results reported in this paper reveal an underlying behavioral aspect of innovative activity. We are aware of at least two other papers that look at the behavioral nature of innovative success namely Galasso and Simcoe (2011) and Hirshleifer et al. (2012), which report a positive relation between chief executive officer (CEO) overconfidence and innovative activity. ${ }^{3}$ There is an important distinction between CEO overconfidence and gambling preferences. While overconfidence refers to CEOs' tendency to overstate their ability to achieve outcomes, gambling preferences refer to a preference for positively skewed investments. In the context of corporate innovation, however, both these behavioral traits result

\footnotetext{
${ }^{2}$ We contrast the $\mathrm{CP}$ ratio proxy with other potential proxies of local gambling preferences in Section II.B, where we also discuss why this proxy has been recognized in the literature as the most appropriate proxy.

${ }^{3}$ Faleye, Kovacs, and Venkateswaran (2014) investigate the impact of CEO connections on innovation. While their study also has a behavioral undertone, it does not explicitly consider concrete behavioral traits.
} 
in corporations being more willing to accept projects that otherwise would have been overlooked due to their high risk and probability of failure. ${ }^{4}$

Despite the potential overlap between CEO overconfidence and gambling preferences in terms of their impact on corporate innovation, CEO overconfidence is a behavioral trait relevant to a single individual, while locally held gambling preferences affect employee preferences at all levels of the organization. Since corporate innovation is dependent on the firm's human capital, behavioral factors relevant to the entire firm would seem more relevant to innovative success than the behavioral traits of a top executive. ${ }^{5}$ In this respect, corporate innovation differs from other areas where the CEO has much greater control over corporate outcomes. ${ }^{6}$ In addition, from the behavioral perspective, overconfidence alone is not a sufficient condition for the CEO to invest in risky projects. Although overconfident CEOs tend to overstate their ability and thus underestimate the risk of R\&D projects, they might overlook these projects if the estimated risk (though downward biased) is still above their risk-tolerance level. Local gambling attitudes encourage individuals to take risks and thus increase the risk tolerance of the CEO. As a result, the CEOs' estimated risk of the R\&D projects is more likely to fall below their risk-tolerance threshold when they are influenced by stronger gambling attitudes. Therefore, we would expect gambling preferences to have a stronger effect on corporate innovation, with overconfident CEOs being more effective in spurring innovation in firms already predisposed to gambling preferences.

Incorporating both option- and press-based measures of CEO overconfidence, we find that social gambling preferences are a more significant driver of innovative inputs and outputs than $\mathrm{CEO}$ overconfidence. Another revealing finding is that CEO overconfidence is more relevant to innovation in areas where gambling attitudes are strong. This is primarily true for firms in innovative industries. This finding is relevant to the extant literature linking CEO overconfidence with finance, as it shows that cultural norms and beliefs are relevant to whether overconfidence of top executives is reflected in managerial decision making.

Our paper contributes to three strands of literature. First, our paper is related to the emerging literature that links attitudes toward risk with innovative activity. Chemmanur, Loutskina, and Tian (2014) and Tian and Wang (2014) show that innovative activity increases with the loss tolerance of investors supplying venture capital. Approaching the issue from a different angle, Galasso and Simcoe (2011) and Hirshleifer et al. (2012) show that overconfident CEOs (who have a

\footnotetext{
${ }^{4}$ Overconfident CEOs overstate their own ability to make R\&D projects successful, thus understating the possibility of potential future losses stemming from their R\&D investments (Hirshleifer et al. (2012)). Overconfident CEOs will therefore invest in research projects that nonoverconfident CEOs would not invest in. Gambling-prone individuals, on the other hand, actively seek projects that have a high positive skewness, with $R \& D$ projects falling into this category. While overconfidence and gambling preferences are different behavioral traits, both these traits make corporate innovation seem more attractive. We thank the referee for forcing us to think about this difference.

${ }^{5}$ Over half of R\&D expenditure covers the wages of highly skilled research employees (Hall (2002)), highlighting the essential role of employees in innovation.

${ }^{6}$ For example, investment policy (Malmendier and Tate (2005)), merger and acquisition decisions (Malmendier and Tate (2008)), and dividend policy (Deshmukh, Goel, and Howe (2013)).
} 
greater propensity to take on higher-risk projects) are better innovators than their nonoverconfident counterparts. We extend this literature by showing that the gambling attitudes of local residents are also important to innovative outcomes, and in fact are more significant contributors to innovation than managerial overconfidence. Our results suggest that due to the nature of innovative activity, factors that have an influence throughout the firm are more relevant than the preferences of a limited group of people.

Second, our paper builds on the empirical literature linking gambling preferences with financial outcomes. We are the first to show that corporate gambling preferences are a key determinant of investment in innovation and innovative output. Prior literature has predominantly concentrated on the gambling preferences of individual investors (Barberis and Huang (2008), Kumar (2009), and Kumar et al. (2011)). Notable exceptions are Shu, Sulaeman, and Yeung (2012) and Schneider and Spalt (2013), who link gambling preferences with investment fund risk taking and takeover decisions. We show that gambling preferences are one of the most important behavioral determinants of corporate investment in innovation and return on investment.

Third, our results complement recent evidence presented by Hilary and Hui (2009), who show that religious adherence at the county level influences corporate policy, including risk exposure and investment. Unlike Hilary and Hui, we concentrate on religious composition rather than religiosity in general and highlight the influence of specific religious beliefs on local norms, namely gambling preferences. Our paper is also related to Kumar et al. (2011), who show that the $\mathrm{CP}$ ratio at the county level is associated with local gambling preferences and market outcomes. While Kumar et al. link local norms with investor stock selection, employee compensation plans, and initial public offering (IPO) returns, we show that religion-induced norms directly influence corporate outcomes pertaining to innovation.

\section{Data and Summary Statistics}

We use numerous data sets to construct our sample. Patent- and citationrelated data are from the 2006 edition of the NBER patent database. Countylevel information on prevalent religious adherence is collected from the American Religion Data Archive (ARDA). All accounting data are from Compustat, stock returns are from the Center for Research in Security Prices (CRSP), and information on CEOs and their compensation is obtained from Standard \& Poor's ExecuComp database. Our sample period extends from Jan. 1980 to Dec. 2006. The sample consists of firms in the intersection of the NBER patent database, ARDA, and Compustat. Firm-years with missing data on control variables and dependent variables are deleted. To make our sample representative, we include all firms in the Compustat database that operate in the same 4-digit Standard Industrial Classification (SIC) code industry as the firms in the patent database. As our sample is very similar to Hirshleifer et al. (2012), meaningful comparisons are feasible between the social gambling effect and the CEO overconfidence effect. ${ }^{7}$

\footnotetext{
${ }^{7}$ Very similar filtering criteria are used, especially for our analysis contrasting the local gambling effect with CEO overconfidence.
} 
The final sample in the intersection of these data sets consists of 34,097 firm-year observations.

\section{A. Measuring Innovation}

We measure innovative activity both as resource input into $\mathrm{R} \& \mathrm{D}$ and research output. Resource input is measured as R\&D spending scaled by book assets. Firmyears with missing $R \& D$ data are assigned a value of 0 and kept in the sample. This approach is consistent with Hirshleifer et al. (2012) and is based on the notion that R\&D spending not reported on a separate line item does not pass the materiality threshold under generally accepted accounting principles (GAAP).

Measures of innovative output are based on patent activity and impact factors of those patents. We use the 2006 edition of the NBER patent database (Hall, Jaffe, and Trajtenberg (2001)), which covers over 3.2 million patent grants and 23.6 million patent citations from 1976 to 2006. The database contains information about patent assignee names and their Compustat-matched identifiers, the number of citations received by each patent, the technology class of the patents, and similar details. Patents are included in the database only if they are eventually granted. Furthermore, there is on average a 2-year lag between patent application and patent grant. Because the latest year in the database is 2006, patents applied for in 2005 and 2006 may not appear in the database. For this reason, in our robustness tests we consider a more restricted period where the sample ends in 2004. This does not materially alter the results.

Our first measure of innovative output is the number of patents granted for each firm in each year. Although innovative output is not directly observable, the patents that firms apply for offer a good indicator of their level of innovative inventions. Since patenting is the only means by which firms can protect their intellectual property, it is feasible to assume that most of a firm's innovative output will be patented. The volume of patents applied for should therefore be a good measure of a company's innovative activity.

Simple patent count captures innovation success imperfectly because patent innovations vary widely in their technological and economic significance. Citations made to a firm's patents can better reflect those patents' technological or economic significance. For this reason, the second measure of innovative output is citations per patent. However, owing to the finite length of the sample, citations suffer from a truncation bias. Because citations are received for many years after a patent is created, patents created in later years have less time to accumulate citations than patents created in earlier years. To address this issue, we adjust the patent citation count of each patent using the weighting index from Hall, Jaffe, and Trajtenberg (2001), (2005), which is provided in the NBER patent database. The weighting index is created using a quasi-structural approach where the shape of the citation-lag distribution is econometrically estimated. As an additional means of dealing with the truncation problem, we include year fixed effects in all our regressions.

\section{B. Measuring Social Gambling Preferences}

Consistent with Kumar et al. (2011), we use a religion-based measure of social gambling preferences at the county level. This measure is the ratio of a 
county's Catholic residents to Protestant residents. Since direct measures of an area's gambling propensity are unavailable, we follow Kumar et al. in identifying gambling propensity by the portion of the Catholic population relative to the Protestant population of a county, drawing on a large body of evidence that shows that Catholics, on average, gamble significantly more. Protestants are typically fervently opposed to all forms of gambling, while Catholics tend to be more tolerant of gambling practices. Consistent with this view, a growing body of literature provides empirical support for the notion that Catholics have a greater propensity to gamble than Protestants (Mikesell (1994), Kumar (2009)). Consistent with their conjecture that the CP ratio is a good predictor of an area's gambling propensity, Kumar et al. find that the $\mathrm{CP}$ ratio of a geographic region is significantly related to both the participation in state lotteries and the holding of stocks with lottery-type features.

The religion-based proxy of social gambling preferences appears to be the best available measure of people's gambling propensity at a local level. Alternative proxies could include socioeconomic attributes such as age, level of education, income, or gender, which are also known to influence people's propensity to gamble (Kumar (2009)); however, these factors exhibit considerably less geographical variation than the religion-based proxy. Furthermore, the direction of the relation between sociological factors and gambling is not as clearly established as the relation between religious beliefs and gambling. For example, Kumar et al. (2011) argue that while the propensity to participate in state lotteries decreases with income, the propensity to engage in other forms of gambling (such as casino gambling and horse racing) increases. Perhaps a more direct proxy would be per capita lottery sales of a region. Unfortunately, data over extended time periods of lottery sales are not readily available at the county level, which would significantly diminish the power of this proxy.

We capture the county-level geographical variation in religious composition using the "Churches and Church Membership" files from ARDA. The data set compiled by the Glenmary Research Center contains county-level statistics for 149 religious bodies, including information on the number of churches and the number of adherents of each church. The county-level religion data are available for the years 1980, 1990, 2000, and 2010. Following previous studies (Alesina and La Ferrara (2002), Hilary and Hui (2009), and Kumar et al. (2011)), we linearly interpolate the data to obtain the values for missing years. We define a firm's location as the location of its headquarters (Coval and Moskowitz (1999), Ivkovic and Weisbenner (2004), and Pirinsky and Wang (2006)). As noted by Pirinsky and Wang, this approach appears "reasonable given that corporate headquarters are close to corporate core business activities." We use the Compustat Company Location Code to match our county information with each firm. This file has numerous missing fields, which we supplement by hand collecting county information from other sources and matching them with city and state names, which tend to be available for most firms. Pirinsky and Wang (2006) and Hilary and Hui (2009) identify a potential issue with this approach in that Compustat only reports the current state and county of a firm's headquarters, which introduces noise in the measurement error if the company has relocated. Nevertheless, the number of firms that relocate is generally small and should 
introduce only a small amount of noise to our results. For example, Pirinsky and Wang find only 118 examples of relocation in a sample of more than 5,000 firms over 15 years.

Variation in religious concentration across the United States may be correlated with other geographic characteristics beyond gambling attitudes that can affect our main dependent variable. In particular, since Kumar et al. (2011) show that Catholics and Protestants cluster in certain geographic areas, some specific characteristics of those areas might be correlated with innovative activity. Due to this relation between our proxy of gambling attitudes and other county demographic characteristics, we include a set of county demographic controls in all our regressions to capture the effect of the $\mathrm{CP}$ ratio per se. The county demographic characteristics include religiosity, population, median age, married ratio, median income, male/female ratio, and minority ratio. ${ }^{8}$ Because Kumar (2009) suggests that many of these factors may be directly related to gambling attitudes, controlling for these demographic factors helps in establishing causality. Including a control for overall level of religiosity of the county ensures that our social gambling preference proxy is independent of religion-induced risk aversion. ${ }^{9}$

\section{Firm-Level Controls}

Following Hall and Ziedonis (2001), we include controls for firm size and capital intensity, where firm size is the natural logarithm of sales. Capital intensity is proxied by the natural logarithm of the ratio of net property, plant, and equipment in 2006 dollars to the number of employees. We calculate R\&D capital as our measure of R\&D inputs. This measure is used as a control for innovative inputs in regressions on innovative outputs. R\&D capital is the 5-year cumulative R\&D expenses assuming an annual depreciation rate of $20 \%$ as in Chan, Lakonishok, and Sougiannis (2001) and Lev, Sarath, and Sougiannis (2005). Thus, for example, R\&D expenses from 5 years back receive a weight of 0.2 (they were amortized $80 \%$ ), those from 4 years back receive a weight of 0.4 , and so forth. Due to the fact that innovation requires a number of years before inputs start being converted into outputs, controlling for R\&D capital is more appropriate than controlling for R\&D expenditure (Pakes and Griliches (1980), Hall, Griliches, and Hausman (1986)).

Additional firm-level controls include return on assets (ROA), book leverage, sales growth, Tobin's Q, and cash holdings. Tobin's Q is defined as the market value to book value of assets; sales growth is the log transformation of sales divided by prior year sales; ROA is the ratio of operating income before depreciation to book assets; book leverage is the ratio of the sum of long-term debt and short-term debt to book assets; and cash holdings is the ratio of cash and assets readily transferable to cash to book assets. Industry fixed effects are included in all regressions, as it is very likely that different industries will have observed levels of innovative activity that have no direct causal relationship with the level of

\footnotetext{
${ }^{8}$ We do not include a control for the level of education, as it is highly correlated with the median income variable.

${ }^{9}$ Hilary and Hui (2009) show that risk aversion increases with religiosity.
} 
gambling preferences expressed at the county level, but reflect other institutional features of the industry. Year fixed effects are also included to remove common macroeconomic shocks.

In addition to standard firm-level controls, we also control for product market competition. Leading industrial organization models of product market competition and innovation predict that more intense product market competition reduces posterity rents and therefore reduces the level of innovation in the market (Salop (1977), Dixit and Stiglitz (1977)). Aghion, Bloom, Blundell, Griffith, and Howitt (2005), in turn, report an inverted U-shaped relationship between product market competition and innovation. Following prior research in the industrial organizations literature (Lindenberg and Ross (1981), Domowitz, Hubbard, and Petersen (1986)) as well as Aghion et al. (2005), we construct our product market pricing power measure based on the Lerner index, which is also referred to as the pricecost margin scaled by sales.

Consistent with Aghion et al. (2013), who find that institutional ownership is related to $R \& D$ spending and research output, we control for the total percentage of shares held by institutions. Institutional ownership data are based on quarterly common stock holdings of 13(f) institutions as compiled by Thomson Reuters. Our measure of institutional ownership is the number of shares held by institutions divided by the total shares outstanding.

Finally, we collate data on analyst coverage. He and Tian (2013) find that firms covered by a larger number of analysts generate fewer patents with lower impact. The data on analyst coverage come from the Institutional Brokers' Estimate System (IBES) Historical Summary File and are available on a monthly basis beginning in 1976. For each firm-year observation, analyst coverage is set equal to the average number of IBES analysts who provide earnings estimates over the four quarters of each calendar year.

\section{CEO Characteristics}

In our final set of results, we examine the interplay between CEO overconfidence and social gambling preferences. This discussion is motivated by Galasso and Simcoe (2011) and Hirshleifer et al. (2012), who show that CEO overconfidence is an important driver of innovation. To identify overconfidence, Malmendier and Tate (2008) exploit the overexposure of CEOs to the idiosyncratic risk of their firms through their holdings of stock options. Following Malmendier and Tate, we define a CEO as overconfident once he postpones the exercise of vested options that are at least 67\% in the money (Holder 67). The Holder 67 variable takes the value of 1 when the CEO is identified as overconfident, and 0 otherwise. In our tests, the CEO overconfidence measures are lagged by one period with respect to the dependent variable.

Since we do not have detailed data on the CEO's option holdings and exercise prices for each option grant, we follow Campbell, Gallmeyer, Johnson, Rutherford, and Stanley (2011) in calculating an average moneyness of the CEO's option portfolio for each year. First, for each CEO-year, we calculate the average realizable value per option by dividing the total realizable value of the options by the number of options held by the CEO. The strike price is calculated as the fiscal year-end 
stock price minus the average realized value. The average moneyness of the options is then calculated as the stock price divided by the estimated strike price. As we are only interested in options that the CEO can exercise, we include only the vested options held by the CEO.

In addition to the option-based measure of CEO overconfidence, we also use a press-based measure from Hirshleifer et al. (2012). The press-based measure involves searching the Factiva database for articles on the CEO in The New York Times, Business Week, Financial Times, The Wall Street Journal, The Economist, Fortune, and Forbes, and recording the number of "confident" and "cautious" references to the CEO. A CEO is then classified as overconfident if the number of "confident" terms exceeds the number of "cautious" terms. Details on constructing the press-based measure can be found in Hirshleifer et al.

Consistent with Hirshleifer et al. (2012), who show that CEO characteristics play a decisive role in innovative activity, we also control for CEO tenure and incentives. Motivated by option pricing theory, we capture CEO incentives using CEO delta and vega. Delta is defined as the dollar change in a CEO's stock and option portfolio for a $1 \%$ change in stock price and measures the CEO's incentives to increase the stock price. Vega is the dollar change in a CEO's option holdings for a 0.01 -unit change in stock return volatility. Vega measures the risktaking incentives generated by the CEO's option holdings. Manso (2011) argues that employment contracts that encourage risk taking are necessary to motivate innovation. We therefore expect to observe a positive relation between vega and innovative activity.

\section{E. Descriptive Statistics}

Table 1 provides the descriptive statistics. For each variable, we report the medians, standard deviations, and total firm-year observations. Descriptive statistics are reported for the full sample as well as the innovative and noninnovative industry subsamples. Consistent with Hirshleifer et al. (2012), an innovative industry is defined as one whose average citations per patent are above the median across all industries (over the entire sample period). ${ }^{10}$ Industries are classified at the 2-digit SIC code level. On average, R\&D expenditure accounts for $5 \%$ of total assets, with firms in innovative industries investing more in innovation than firms in noninnovative industries. We find that the innovative output measures used in this study (patent count and citations per patent) are highly skewed. To overcome this issue, we take the natural logarithm of these variables. The average log-transformed patent count and citations per patent are 0.49 and 0.33 , respectively. Both measures are higher for firms in innovative industries.

\footnotetext{
${ }^{10}$ We believe that this broad definition of industry innovativeness is most appropriate when considering the effect that social gambling attitudes have on innovative activity across industries. An alternative approach would be to classify industries year by year (identify industries that have a citationsper-patent count above the median figure for all industries in a given year). This alternative approach, however, would mainly capture the year-specific relative performance of individual industries rather than whether they in general require higher levels of innovation.
} 
TABLE 1

Descriptive Statistics

Table 1 reports the descriptive statistics of the key variables. The sample period is from Jan. 1980 to Dec. 2006. We split the sample into firms that are in innovative industries and firms in noninnovative industries. An innovative industry is defined as one whose average citations-per-patent count is above the median across all industries. Patent data are from the NBER patent database, county-level religion data are obtained from the ARDA database, and county-level demographic characteristics are from the U.S. Census Bureau database, while accounting data are from Compustat. Variable definitions are provided in the Appendix.

\begin{tabular}{|c|c|c|c|c|c|c|c|c|c|c|c|c|}
\hline & \multicolumn{4}{|c|}{ Full Sample } & \multicolumn{4}{|c|}{ Innovative Industry } & \multicolumn{4}{|c|}{ Noninnovative Industry } \\
\hline & Mean & Median & $\begin{array}{l}\text { Std. } \\
\text { Dev. }\end{array}$ & $\begin{array}{l}\text { No. of } \\
\text { Obs. }\end{array}$ & Mean & Median & $\begin{array}{l}\text { Std. } \\
\text { Dev. }\end{array}$ & $\begin{array}{l}\text { No. of } \\
\text { Obs. }\end{array}$ & Mean & Median & $\begin{array}{l}\text { Std. } \\
\text { Dev. }\end{array}$ & $\begin{array}{l}\text { No. of } \\
\text { Obs. }\end{array}$ \\
\hline \multicolumn{13}{|l|}{ Dependent Variable } \\
\hline$R \& D /$ Assets & 0.05 & 0.00 & 0.17 & 34,097 & 0.07 & 0.00 & 0.16 & 21,256 & 0.05 & 0.00 & 0.17 & 12,841 \\
\hline Patent count & 7.81 & 0.00 & 81.20 & 34,097 & 8.13 & 0.00 & 79.21 & 21,256 & 7.60 & 0.00 & 84.34 & 12,841 \\
\hline $\ln (1+$ Patent count $)$ & 0.49 & 0.00 & 1.08 & 34,097 & 0.50 & 0.00 & 1.05 & 21,256 & 0.48 & 0.00 & 1.04 & 12,841 \\
\hline Citations per patent & 1.75 & 0.00 & 1.79 & 34,097 & 2.50 & 0.00 & 5.94 & 21,256 & 1.34 & 0.00 & 5.29 & 12,841 \\
\hline $\ln (1+$ Citations per patent $)$ & 0.33 & 0.00 & 0.79 & 34,097 & 0.40 & 0.00 & 0.85 & 21,256 & 0.31 & 0.00 & 0.79 & 12,841 \\
\hline \multicolumn{13}{|c|}{ County-Level Explanatory Variables } \\
\hline CP ratio & 2.02 & 1.17 & 1.78 & 34,097 & 2.03 & 1.18 & 1.79 & 21,256 & 2.02 & 1.16 & 1.79 & 12,841 \\
\hline ratio) & 0.94 & 0.94 & 0.57 & 34,097 & 0.94 & 0.95 & 0.56 & 21,256 & 0.94 & 0.94 & 0.57 & 12,841 \\
\hline yiosity & 0.53 & 0.53 & 0.12 & 34,097 & 0.53 & 0.53 & 0.12 & 21,256 & 0.53 & 0.53 & 0.1 & 12,841 \\
\hline tion) & 13.54 & 13.64 & 1.18 & 34,097 & 13.55 & 13.65 & 1.18 & 21,256 & 13.53 & 13.62 & & 12,841 \\
\hline ledian & 3.54 & 3.53 & 0.07 & 34,097 & 3.54 & 3.54 & 0.07 & 21,256 & 3.54 & 3.53 & 0.07 & 12,841 \\
\hline ied ratio & 0.50 & 0.51 & 0.08 & 34,097 & 0.50 & 0.51 & 0.08 & 21,256 & 0.50 & 0.51 & 0.08 & 12,841 \\
\hline come) & 10.72 & 10.69 & 0.25 & 34,097 & 10.72 & 10.69 & 0.25 & 21,256 & 10.72 & 10.70 & 0.2 & 12,841 \\
\hline le ratio & 0.96 & 0.96 & 0.04 & 34,097 & 0.96 & 0.96 & 0.04 & 21,256 & 0.96 & 0.96 & 0.0 & 12,841 \\
\hline Minority ratio & 0.27 & 0.26 & 0.15 & 34,097 & 0.27 & 0.26 & 0.15 & 21,256 & 0.27 & 0.26 & 0.14 & 12,841 \\
\hline \multicolumn{13}{|c|}{ Firm-Level Explanatory Variables } \\
\hline In(R\&D capital) & 0.64 & 0.00 & 1.49 & & 0.67 & 0.00 & 1.58 & & 0.59 & 0.00 & 1.44 & 12,841 \\
\hline ales) & 5.62 & 5.57 & 2.14 & 34,097 & 5.62 & 5.59 & 2.15 & 21,256 & 5.60 & 5.55 & & 12,841 \\
\hline PE/EMP) & 3.62 & 3.46 & 1.33 & 34,097 & 3.62 & 3.46 & 1.30 & 21,256 & 3.63 & 3.47 & 1.40 & 12,841 \\
\hline ROA & 0.07 & 0.12 & 0.31 & 34,097 & 0.08 & 0.12 & 0.25 & 21,256 & 0.07 & 0.12 & 0.38 & 12,841 \\
\hline Book leverage & 0.22 & 0.18 & 0.23 & 34,097 & 0.22 & 0.17 & 0.23 & 21,256 & 0.22 & 0.16 & 0.24 & 12,841 \\
\hline rowth & 0.16 & 0.11 & 0.44 & 34,097 & 0.16 & 0.11 & 0.43 & 21,256 & 0.16 & 0.11 & 0.45 & 12,841 \\
\hline Tob & 1.81 & 1.13 & 9.49 & 34,097 & 1.83 & 1.13 & 9.34 & 21,256 & 1.78 & 1.13 & 9.39 & 12,841 \\
\hline Cash holdings & 0.19 & 0.09 & 0.22 & 34,097 & 0.19 & & 0.23 & & 0.19 & 0.10 & 0.22 & 12,841 \\
\hline Lerner index & 0.09 & 0.14 & 86.03 & 34,097 & 0.04 & 0.13 & 42.09 & 21,256 & 0.12 & 0.13 & 95.11 & 12,841 \\
\hline Total IO & 0.44 & 0.44 & 0.26 & 34,097 & 0.45 & 0.46 & 0.26 & 21,256 & 0.44 & 0.43 & 0.26 & 12,841 \\
\hline In(Analysts) & 1.63 & 1.52 & 0.74 & 34,097 & 1.64 & 1.52 & 0.74 & 21,256 & 1.62 & 1.50 & 0.73 & 12,841 \\
\hline
\end{tabular}

The average $\mathrm{CP}$ ratio, measured at the firm level, is 2.02 , while the average log-transformed CP ratio is $0.94 .{ }^{11}$ This measure is the same in innovative and noninnovative industries. We take the natural logarithm of the $\mathrm{CP}$ ratio to deal with the skewness of the raw $\mathrm{CP}$ ratio evident from the descriptive statistics. On average, $53 \%$ of county residents are religious. The married ratio is 0.5 , while the average male/female ratio is 0.96 . This means that for every female resident, there are 0.96 males. Finally, 27\% of sample county residents are regarded as nonwhites. The demographic characteristics of sample counties are very similar between innovative and noninnovative industries.

Consistent with prior literature, we take the natural logarithm of sales and scaled property, plant, and equipment. The average log-transformed R\&D capital is 0.64 , with innovative inputs being higher in innovative than noninnovative

\footnotetext{
${ }^{11}$ The average CP ratio of 2.02 reported in Table 1 is considerably higher than the average CP ratio of 0.60 reported in Kumar et al. (2011). The reason for this discrepancy is that Kumar et al. report descriptive statistics at the county level, while we report our statistics at the firm level. When calculated at the county level, the average CP ratio in our sample is 0.63 , which is close to that in Kumar et al.
} 
industries (0.67 vs. 0.59). Average ROA is 0.07 , book leverage is 0.22 , sales growth is 0.16 , Tobin's Q is 1.81 , and cash holdings are 0.19 . The average Lerner index score is 0.09 , average level of institutional ownership is 0.44 , and the logtransformed analyst following is 1.63 .

\section{Social Gambling Preferences and Corporate Risk Taking}

We hypothesize that firms located in areas where gambling is more socially accepted undertake more risky projects. For this reason, we begin our empirical analysis by examining the relation between the $\mathrm{CP}$ ratio and overall firm volatility. We use two proxies of firm volatility: stock return volatility and profit volatility. Stock return volatility is measured as the standard deviation of daily stock returns, expressed in percentage terms. ${ }^{12}$ Since stock return volatility can be driven by investor behavior (Kumar (2009)), we also utilize a firm-specific proxy of the risk undertaken by firms in the form of profit volatility. Profit volatility is generated from the Compustat Fundamental Quarter files. We first calculate the profitability ratio as income before extraordinary items divided by book assets. Next, we calculate the standard deviation of the ratio over the following 20 quarters, where at least 8 quarters' data are required. The results are presented in Table 2. We use two specifications for both dependent variables: In the first specification, only $\ln (\mathrm{CP}$ ratio) together with year and industry fixed effects are included; in the second specification, firm-level controls are included on top of $\ln (\mathrm{CP}$ ratio) and year and industry fixed effects. Standard errors are clustered at the firm level.

The results reveal a strong positive relation between $\ln (\mathrm{CP}$ ratio) of a county and firm volatility. In column (2), where the dependent variable is stock return volatility, the coefficient estimate on $\ln (\mathrm{CP}$ ratio $)$ is 0.01 . This means that a 1 -standard-deviation increase in $\ln (\mathrm{CP}$ ratio) (0.57) is associated with a 0.57 basis-point increase in daily stock return volatility. The economic and statistical significance of the $\ln (\mathrm{CP}$ ratio) coefficient reported in column (4), the regression linking gambling attitudes with profit volatility, is lower (0.008) but still significant.

The results presented in Table 2 lend support to the view that firms headquartered in counties with higher $\mathrm{CP}$ ratios tend to take on higher levels of risk than firms headquartered in counties dominated by Protestant values. These results build on Kumar et al. (2011), in showing that the CP ratio is a reliable proxy of social gambling attitudes. Furthermore, the results support the view that the social norms/views expressed by county residents are reflected in corporate behavior.

Consistent with prior literature, Table 2 shows that small, high-growth, and highly leveraged firms as well as firms with high cash levels tend to have higher risk. In contrast, capital-intensive firms and firms with higher ROA assume less risky projects.

\footnotetext{
${ }^{12}$ In unreported additional tests, we use an idiosyncratic volatility measure as a proxy of risk taking, which yields identical results.
} 
TABLE 2

Gambling Preferences and Firm Volatility

Table 2 presents the estimates of regressions of the riskiness of company projects (stock return volatility and profit volatility) on the CP ratio. The first measure of riskiness is stock return volatility. Stock return volatility is the standard deviation of daily stock returns over the fiscal year, in percentage. The second measure is profit volatility. Profit volatility is the standard deviation of firm profitability over the subsequent 5 years. All independent variables are lagged by 1 year. All regressions include year and industry fixed effects, defined based on 2-digit SIC codes. Intercepts are not reported. Standard errors are corrected for clustering of observations at the firm level (t-statistics are in parentheses); ${ }^{*},{ }^{\star *}$, and ${ }^{* \star *}$ measure significance at the $10 \%, 5 \%$, and $1 \%$ levels, respectively; and variable definitions are provided in the Appendix.

Dependent Variable

\begin{tabular}{|c|c|c|c|c|}
\hline & & & & \\
\hline & & Satility & & \\
\hline & (1) & (2) & (3) & (4) \\
\hline In(CP ratio) & $\begin{array}{l}0.05 \\
\left(9.63^{\star \star \star}\right)\end{array}$ & $\begin{array}{l}0.01 \\
\left(3.87^{\star * \star}\right)\end{array}$ & $\begin{array}{l}0.02 \\
\left(9.66^{\star \star \star}\right)\end{array}$ & $\begin{array}{c}0.008 \\
\left(3.60^{\star \star *}\right)\end{array}$ \\
\hline In(Sales) & & $\begin{array}{c}-0.61 \\
\left(-10.86^{\star \star \star}\right)\end{array}$ & & $\begin{array}{c}-0.01 \\
\left(-11.94^{\star \star \star}\right)\end{array}$ \\
\hline In(PPE/EMP) & & $\begin{array}{c}-0.006 \\
\left(-10.02^{\star \star \star}\right)\end{array}$ & & $\begin{array}{l}-0.003 \\
\left(-5.96^{\star \star \star}\right)\end{array}$ \\
\hline $\mathrm{ROA}$ & & $\begin{array}{l}-0.03 \\
\left(-2.56^{\star \star}\right)\end{array}$ & & $\begin{array}{l}-0.04 \\
\left(-3.29^{\star \star \star}\right)\end{array}$ \\
\hline Book leverage & & $\begin{array}{l}0.04 \\
\left(8.74^{\star \star \star}\right)\end{array}$ & & $\begin{array}{l}0.02 \\
\left(5.50^{\star \star *}\right)\end{array}$ \\
\hline Sales growth & & $\begin{array}{l}0.02 \\
\left(9.64^{\star \star \star}\right)\end{array}$ & & $\begin{array}{l}0.007 \\
\left(5.48^{\star \star \star}\right)\end{array}$ \\
\hline Tobin's Q & & $\begin{array}{l}0.001 \\
(1.62)\end{array}$ & & $\begin{array}{l}0.01 \\
\left(3.05^{\star \star \star}\right)\end{array}$ \\
\hline Cash holdings & & $\begin{array}{c}0.08 \\
\left(15.27^{\star \star \star}\right)\end{array}$ & & $\begin{array}{l}0.04 \\
\left(9.73^{\star \star \star}\right)\end{array}$ \\
\hline Total IO & & $\begin{array}{l}-0.001 \\
(-1.31)\end{array}$ & & $\begin{array}{l}-0.0008 \\
(-1.18)\end{array}$ \\
\hline In(Analysts) & & $\begin{array}{l}0.006 \\
\left(4.00^{* \star \star}\right)\end{array}$ & & $\begin{array}{c}0.006 \\
\left(5.65^{* * *}\right)\end{array}$ \\
\hline $\begin{array}{l}\text { Year fixed effects } \\
\text { Industry fixed effects }\end{array}$ & $\begin{array}{l}\text { Yes } \\
\text { Yes }\end{array}$ & $\begin{array}{l}\text { Yes } \\
\text { Yes }\end{array}$ & $\begin{array}{l}\text { Yes } \\
\text { Yes }\end{array}$ & $\begin{array}{l}\text { Yes } \\
\text { Yes }\end{array}$ \\
\hline $\begin{array}{l}\text { No. of obs. } \\
\text { Adj. } R^{2}\end{array}$ & $\begin{array}{l}90,762 \\
0.09\end{array}$ & $\begin{array}{c}25,604 \\
0.25\end{array}$ & $\begin{array}{c}138,740 \\
0.07\end{array}$ & $\begin{array}{c}29,158 \\
0.30\end{array}$ \\
\hline
\end{tabular}

\section{Local Gambling Preferences and Innovative Activity}

\section{A. R\&D Expenditure}

To test whether increased social propensity to gamble surrounding a firm's headquarters results in increased $R \& D$ spending, we use $R \& D$ expenditure scaled by assets as the dependent variable in the regression of Table 3 . The control variables are similar to Coles, Daniel, and Naveen (2006) and Hirshleifer et al. (2012). Four specifications are used: In the first, only the CP ratio, firm-level controls, and industry and year fixed effects are included; in the second, we include additional firm-level controls, such as product market competition, total institutional ownership, and analyst following (this reduces the sample from 103,598 firm-year observations to 31,757 firm-year observations); and in the third specification, we add county demographic characteristics. In the fourth specification, we include county fixed effects on top of industry and year fixed effects. Consistent with Kumar et al. (2011), we exclude all variables that are measured at the county level in the county fixed effects regression. Standard errors are clustered at the firm level. 
TABLE 3

Gambling Preferences and R\&D Expenditure

Table 3 presents the regression results on the relation between the $\mathrm{CP}$ ratio and R\&D expenditure. The dependent variable is the ratio of R\&D expenditure to book assets. Missing values of R\&D are coded with 0 . All independent variables are lagged by 1 year. Inclusion of year, industry, and county fixed effects is indicated at the bottom of each column. Intercepts are not reported. Standard errors are corrected for clustering of observations at the firm level ( $t$-statistics are in parentheses); ${ }^{*},{ }^{* *}$, and ${ }^{\star \star *}$ measure significance at the $10 \%, 5 \%$, and $1 \%$ levels, respectively; and variable definitions are provided in the Appendix.

Dependent Variable: R\&D/Assets

\begin{tabular}{|c|c|c|c|c|}
\hline & & (ट) & (3) & (4) \\
\hline In(CP ratio) & $\begin{array}{l}0.02 \\
\left(6.28^{\star \star \star}\right)\end{array}$ & $\begin{array}{l}0.02 \\
\left(3.95^{\star \star \star}\right)\end{array}$ & $\begin{array}{l}0.01 \\
\left(4.44^{\star \star \star}\right)\end{array}$ & $\begin{array}{l}0.005 \\
\left(2.04^{\star \star}\right)\end{array}$ \\
\hline In(Sales) & $\begin{array}{l}-0.01 \\
\left(-6.16^{\star \star \star}\right)\end{array}$ & $\begin{array}{c}-0.01 \\
\left(-4.40^{\star \star \star}\right)\end{array}$ & $\begin{array}{c}-0.009 \\
\left(-2.82^{\star \star \star}\right)\end{array}$ & $\begin{array}{l}-0.007 \\
(-1.22)\end{array}$ \\
\hline In(PPE/EMP) & $\begin{array}{c}-0.004 \\
\left(-4.68^{* * *}\right)\end{array}$ & $\begin{array}{l}-0.002 \\
(-1.25)\end{array}$ & $\begin{array}{l}-0.0005 \\
(-0.46)\end{array}$ & $\begin{array}{l}-0.002 \\
(-0.86)\end{array}$ \\
\hline $\mathrm{ROA}$ & $\begin{array}{l}-0.06 \\
\left(-3.14^{\star \star \star}\right)\end{array}$ & $\begin{array}{c}-0.07 \\
(-1.50)\end{array}$ & $\begin{array}{l}-0.13 \\
\left(-1.83^{\star}\right)\end{array}$ & $\begin{array}{l}-0.28 \\
\left(-2.56^{\star \star}\right)\end{array}$ \\
\hline Book leverage & $\begin{array}{c}-0.007 \\
\left(-2.07^{\star *}\right)\end{array}$ & $\begin{array}{c}0.02 \\
(1.26)\end{array}$ & $\begin{array}{c}0.03 \\
(1.42)\end{array}$ & $\begin{array}{l}-0.002 \\
(-0.17)\end{array}$ \\
\hline Sales growth & $\begin{array}{l}0.01 \\
\left(4.04^{\star * *}\right)\end{array}$ & $\begin{array}{l}0.01 \\
\left(2.22^{\star \star}\right)\end{array}$ & $\begin{array}{c}0.006 \\
\left(1.95^{\star}\right)\end{array}$ & $\begin{array}{c}0.008 \\
\left(2.17^{\star \star}\right)\end{array}$ \\
\hline Tobin's Q & $\begin{array}{l}0.00004 \\
(1.47)\end{array}$ & $\begin{array}{r}0.001 \\
(1.19)\end{array}$ & $\begin{array}{l}0.0006 \\
(1.59)\end{array}$ & $\begin{array}{r}0.0007 \\
\left(1.98^{\star *}\right)\end{array}$ \\
\hline Cash holdings & $\begin{array}{l}0.15 \\
\left(4.27^{\star * \star}\right)\end{array}$ & $\begin{array}{c}0.22 \\
\left(13.42^{\star \star \star}\right)\end{array}$ & $\begin{array}{c}0.21 \\
\left(20.49^{\star \star \star}\right)\end{array}$ & $\begin{array}{c}0.15 \\
\left(15.98^{\star \star \star}\right)\end{array}$ \\
\hline Lerner index & & $\begin{array}{c}-0.001 \\
\left(-2.17^{\star \star}\right)\end{array}$ & $\begin{array}{l}-0.0003 \\
\left(-2.04^{\star \star}\right)\end{array}$ & $\begin{array}{l}-0.0003 \\
\left(-1.98^{\star \star}\right)\end{array}$ \\
\hline Total IO & & $\begin{array}{c}0.002 \\
(1.26)\end{array}$ & $\begin{array}{c}0.002 \\
(1.32)\end{array}$ & $\begin{array}{c}0.004 \\
\left(2.01^{\star *}\right)\end{array}$ \\
\hline In(Analysts) & & $\begin{array}{l}0.01 \\
\left(4.91^{\star \star \star}\right)\end{array}$ & $\begin{array}{c}0.008 \\
\left(4.45^{\star \star \star}\right)\end{array}$ & $\begin{array}{c}0.01 \\
\left(2.73^{\star \star \star}\right)\end{array}$ \\
\hline Religiosity & & & $\begin{array}{l}-0.09 \\
\left(-5.60^{\star \star *}\right)\end{array}$ & \\
\hline In(Population) & & & $\begin{array}{l}-0.002 \\
\left(-1.68^{\star}\right)\end{array}$ & \\
\hline In(Median age) & & & $\begin{array}{l}-0.07 \\
\left(-1.75^{\star}\right)\end{array}$ & \\
\hline Married ratio & & & $\begin{array}{c}0.03 \\
(1.10)\end{array}$ & \\
\hline In(Median income) & & & $\begin{array}{l}0.05 \\
\left(7.68^{\star \star \star}\right)\end{array}$ & \\
\hline Male/Female ratio & & & $\begin{array}{c}-0.11 \\
\left(-2.43^{\star \star}\right)\end{array}$ & \\
\hline Minority ratio & & & $\begin{array}{l}-0.0001 \\
(-0.05)\end{array}$ & \\
\hline Year fixed effects & Yes & Yes & Yes & Yes \\
\hline Industry fixed effects & Yes & Yes & Yes & Yes \\
\hline County fixed effects & No & No & No & Yes \\
\hline No. of obs. & 103,598 & 31,757 & 31,757 & 31,757 \\
\hline Adj. $R^{2}$ & 0.15 & 0.23 & 0.25 & 0.34 \\
\hline
\end{tabular}

Column (1) of Table 3 shows a positive relation between $\ln (\mathrm{CP}$ ratio) and R\&D spending. The coefficient of 0.02 shows that a 1 -standard-deviation increase in $\ln (\mathrm{CP}$ ratio) leads to an increase of 0.0114 in $\mathrm{R} \& \mathrm{D}$ spending as a portion of total assets. Relative to the unconditional mean of R\&D/Assets $(0.05$ from Table 1), this represents an increase of over $20 \%$. The results do not change after controlling for product market competition, total institutional ownership, and analyst following (reported in column (2)). After controlling for county demographic 
characteristics (column (3)), the coefficient estimate on $\ln (\mathrm{CP}$ ratio) falls to 0.01 but retains its statistical significance. Relative to the unconditional mean of $\mathrm{R} \& \mathrm{D} /$ Assets from Table 1, a 1-standard-deviation increase in $\ln (\mathrm{CP}$ ratio) still represents an increase of over $11 \%$ after including all controls. These results suggest that the social norms that surround corporate headquarters (pertaining to gambling preferences) are relevant in determining corporate investment decisions.

Although we control for a large number of county-specific factors in column (3) of Table 3, there might still be other factors unique to individual counties that are driving our results. For this reason, in column (4) we include county fixed effects in our regression analysis. The inclusion of county fixed effects rules out simple stories such as a time-invariant big-city effect. Although the coefficient estimate on $\ln (\mathrm{CP}$ ratio) decreases in magnitude and significance after including county fixed effects, the fact that the coefficient remains positive and statistically significant suggests that the results reported in the baseline setting are not merely driven by some county-specific omitted variables. ${ }^{13}$

While we are unable to trace the exact route through which increased gambling preferences translate into greater $\mathrm{R} \& \mathrm{D}$ expenditure, it is clear that greater gambling predisposition makes it easier for firms to motivate investment in innovation.

Looking at the coefficient estimates on the control variables, we find that relative investment in innovation decreases with firm size. In contrast, firms experiencing higher growth in sales and armed with higher cash reserves spend considerably more on innovation. Consistent with industrial organization models, R\&D expenditure falls with the level of product market competition, while firms with greater analyst following tend to spend more on innovation. Among the county demographic characteristics, we observe a negative relation between religiosity and $\mathrm{R} \& \mathrm{D}$ expenditure, which is in contrast with the positive coefficients estimated for $\ln (\mathrm{CP}$ ratio) in three models. This observation is consistent with the argument that the level of religiosity is positively related to risk aversion, while the CP ratio captures more than religiosity. Finally, R\&D expenditure tends to be greater in less populated counties, counties with a younger population, more affluent counties, and counties with greater male populations.

\section{B. Innovative Output}

We now examine the relation between social gambling attitudes and innovative outcomes. The results are presented in Table 4 . The dependent variables are measures of innovative output: the natural logarithm of 1 plus patent count, and the natural logarithm of 1 plus citations per patent. Patent count measures the raw volume of innovative inventions, while citations per patent measures the

\footnotetext{
${ }^{13}$ The lower magnitude and statistical significance of the coefficient of interest is explained by the fact that the $\mathrm{CP}$ ratio varies considerably less over time than in the cross section. The average timeseries standard deviation of the CP ratio is 0.12 , compared with the average cross-sectional standard deviation of 1.12 . Although the $\mathrm{CP}$ ratio of a single county is relatively stable over time, the average time-series standard deviation of 0.12 is significant as compared with the sample mean CP ratio of 0.63. The magnitude of this change is sufficient to expect gambling preferences to change over time, which will have an effect on innovative activity.
} 
TABLE 4

Gambling Preferences and Innovation Outcomes

Table 4 presents the regression results on the association between the CP ratio and innovative outcomes (patent count and citations per patent). In columns (1)-(3), the dependent variable is the natural logarithm of the number of patents applied for in a given year. In columns (4)-(6), the dependent variable is the natural logarithm of the number of times that patents applied for in a given year were subsequently cited by other patents. All independent variables are lagged by 1 year. Inclusion of year, industry, and county fixed effects is indicated at the bottom of each column. Intercepts are not reported. Standard errors are corrected for clustering of observations at the firm level (t-statistics are in parentheses); * ${ }^{\star *}$, and ${ }^{* * *}$ measure significance at the 10\%,5\%, and 1\% levels, respectively; and variable definitions are provided in the Appendix.

Dependent Variable

\begin{tabular}{|c|c|c|c|c|c|c|}
\hline & \multicolumn{3}{|c|}{$\ln (1+$ Patent count $)$} & \multicolumn{3}{|c|}{$\ln (1+$ Citations per patent $)$} \\
\hline & $(1)$ & $(2)$ & (3) & $(4)$ & $(5)$ & (6) \\
\hline $\ln (\mathrm{CP}$ ratio) & $\begin{array}{l}0.05 \\
\left(2.54^{\star \star}\right)\end{array}$ & $\begin{array}{l}0.07 \\
\left(2.79^{\star \star}\right)\end{array}$ & $\begin{array}{c}0.04 \\
\left(1.85^{\star}\right)\end{array}$ & $\begin{array}{l}0.04 \\
\left(3.14^{* * *}\right)\end{array}$ & $\begin{array}{l}0.07 \\
\left(4.54^{\star \star \star}\right)\end{array}$ & $\begin{array}{c}0.06 \\
\left(1.70^{\star}\right)\end{array}$ \\
\hline In(R\&D capital) & $\begin{array}{c}0.29 \\
\left(29.01^{\star \star \star}\right)\end{array}$ & $\begin{array}{c}0.28 \\
\left(28.50^{\star \star \star}\right)\end{array}$ & $\begin{array}{c}0.27 \\
\left(27.86^{\star \star *}\right)\end{array}$ & $\begin{array}{c}0.13 \\
\left(31.60^{\star \star \star}\right)\end{array}$ & $\begin{array}{c}0.13 \\
\left(30.15^{\star \star \star}\right)\end{array}$ & $\begin{array}{c}0.14 \\
\left(32.19^{\star \star \star}\right)\end{array}$ \\
\hline In(Sales) & 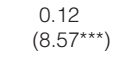 & $\begin{array}{l}0.12 \\
\left(9.00^{\star \star \star}\right)\end{array}$ & $\begin{array}{l}0.10 \\
\left(9.02^{* \star \star}\right)\end{array}$ & $\begin{array}{l}0.05 \\
\left(8.08^{* * *}\right)\end{array}$ & $\begin{array}{l}0.05 \\
\left(9.14^{\star \star *}\right)\end{array}$ & $\begin{array}{c}0.03 \\
\left(5.28^{\star \star \star}\right)\end{array}$ \\
\hline $\ln (P P E / E M P)$ & $\begin{array}{l}0.05 \\
\left(6.61^{\star \star \star}\right)\end{array}$ & $\begin{array}{l}0.05 \\
\left(6.88^{\star \star \star}\right)\end{array}$ & $\begin{array}{l}0.08 \\
\left(8.82^{* * *}\right)\end{array}$ & $\begin{array}{l}0.02 \\
\left(3.83^{* * *}\right)\end{array}$ & $\begin{array}{l}0.02 \\
\left(4.10^{\star \star \star}\right)\end{array}$ & $\begin{array}{l}0.04 \\
\left(6.16^{\star \star \star}\right)\end{array}$ \\
\hline $\mathrm{ROA}$ & $\begin{array}{l}-0.02 \\
(-0.56)\end{array}$ & $\begin{array}{l}-0.02 \\
(-0.59)\end{array}$ & $\begin{array}{l}0.44 \\
\left(3.71^{\star \star \star}\right)\end{array}$ & $\begin{array}{c}0.01 \\
(0.96)\end{array}$ & $\begin{array}{c}0.01 \\
(0.80)\end{array}$ & $\begin{array}{c}0.31 \\
\left(3.90^{\star \star \star}\right)\end{array}$ \\
\hline Book leverage & $\begin{array}{l}-0.11 \\
\left(-1.98^{\star}\right)\end{array}$ & $\begin{array}{l}-0.09 \\
\left(-1.85^{\star}\right)\end{array}$ & $\begin{array}{c}-0.19 \\
\left(-4.16^{\star \star \star}\right)\end{array}$ & $\begin{array}{c}-0.13 \\
\left(-2.60^{\star \star \star}\right)\end{array}$ & $\begin{array}{c}-0.12 \\
\left(-2.55^{\star \star}\right)\end{array}$ & $\begin{array}{l}-0.20 \\
\left(-6.50^{\star * *}\right)\end{array}$ \\
\hline Sales growth & $\begin{array}{l}-0.05 \\
\left(-4.25^{\star \star \star}\right)\end{array}$ & $\begin{array}{c}-0.06 \\
\left(-4.68^{\star \star \star}\right)\end{array}$ & $\begin{array}{l}-0.07 \\
\left(-4.88^{\star \star \star}\right)\end{array}$ & $\begin{array}{c}0.004 \\
(0.37)\end{array}$ & $\begin{array}{c}0.001 \\
(0.08)\end{array}$ & $\begin{array}{l}-0.008 \\
(-0.69)\end{array}$ \\
\hline Tobin's Q & $\begin{array}{c}0.002 \\
\left(2.07^{\star \star}\right)\end{array}$ & $\begin{array}{c}0.002 \\
\left(2.11^{\star \star}\right)\end{array}$ & $\begin{array}{l}0.0005 \\
(0.77)\end{array}$ & $\begin{array}{c}0.001 \\
\left(1.77^{\star}\right)\end{array}$ & $\begin{array}{c}0.001 \\
\left(1.80^{*}\right)\end{array}$ & $\begin{array}{l}-0.0002 \\
(-0.57)\end{array}$ \\
\hline Cash holdings & $\begin{array}{c}1.19 \\
\left(14.86^{\star \star \star}\right)\end{array}$ & 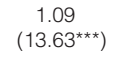 & $\begin{array}{l}0.62 \\
\left(7.51^{* * *}\right)\end{array}$ & $\begin{array}{c}0.76 \\
\left(16.36^{\star * *}\right)\end{array}$ & $\begin{array}{c}0.69 \\
\left(15.14^{\star \star \star}\right)\end{array}$ & 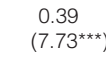 \\
\hline Lerner index & $\begin{array}{l}-0.0002 \\
\left(-1.77^{\star}\right)\end{array}$ & $\begin{array}{l}-0.0002 \\
\left(-1.65^{\star}\right)\end{array}$ & $\begin{array}{c}-0.001 \\
\left(-2.40^{\star \star}\right)\end{array}$ & $\begin{array}{l}-0.0001 \\
\left(-1.77^{\star}\right)\end{array}$ & $\begin{array}{l}-0.0001 \\
(-1.59)\end{array}$ & $\begin{array}{l}-0.002 \\
\left(-3.20^{\star * \star}\right)\end{array}$ \\
\hline Total IO & $\begin{array}{l}0.06 \\
\left(3.40^{\star \star \star}\right)\end{array}$ & $\begin{array}{l}0.06 \\
\left(3.59^{\star \star \star}\right)\end{array}$ & $\begin{array}{l}0.04 \\
\left(3.17^{\star \star \star}\right)\end{array}$ & $\begin{array}{l}0.03 \\
\left(3.05^{\star \star \star}\right)\end{array}$ & $\begin{array}{l}0.03 \\
\left(3.30^{\star \star \star}\right)\end{array}$ & $\begin{array}{c}0.03 \\
\left(3.15^{\star \star \star}\right)\end{array}$ \\
\hline In(Analysts) & $\begin{array}{l}0.15 \\
\left(5.80^{\star \star \star}\right)\end{array}$ & $\begin{array}{l}0.15 \\
\left(5.72^{\star \star \star}\right)\end{array}$ & $\begin{array}{c}0.25 \\
\left(10.03^{* * *}\right)\end{array}$ & $\begin{array}{l}0.05 \\
\left(3.90^{\star \star *}\right)\end{array}$ & $\begin{array}{l}0.05 \\
\left(3.66^{\star \star \star}\right)\end{array}$ & $\begin{array}{l}0.11 \\
\left(7.04^{\star \star \star}\right)\end{array}$ \\
\hline Religiosity & & $\begin{array}{l}-0.67 \\
\left(-4.68^{\star \star \star}\right)\end{array}$ & & & $\begin{array}{l}-0.54 \\
\left(-5.62^{\star \star \star}\right)\end{array}$ & \\
\hline In(Population) & & $\begin{array}{c}-0.02 \\
(-1.16)\end{array}$ & & & $\begin{array}{c}-0.01 \\
(-1.25)\end{array}$ & \\
\hline In(Median age) & & $\begin{array}{l}-0.27 \\
(-1.15)\end{array}$ & & & $\begin{array}{c}-0.34 \\
\left(-2.16^{\star \star}\right)\end{array}$ & \\
\hline Married ratio & & $\begin{array}{c}0.68 \\
\left(2.89^{\star \star \star}\right)\end{array}$ & & & $\begin{array}{c}0.22 \\
(1.60)\end{array}$ & \\
\hline In(Median income) & & $\begin{array}{l}0.25 \\
\left(3.03^{\star \star \star}\right)\end{array}$ & & & $\begin{array}{l}0.19 \\
\left(3.93^{\star \star \star}\right)\end{array}$ & \\
\hline Male/Female ratio & & $\begin{array}{c}0.63 \\
(1.38)\end{array}$ & & & $\begin{array}{l}0.60 \\
\left(1.84^{\star}\right)\end{array}$ & \\
\hline Minority ratio & & $\begin{array}{l}-0.06 \\
(-0.42)\end{array}$ & & & $\begin{array}{l}-0.22 \\
\left(-2.43^{\star \star}\right)\end{array}$ & \\
\hline Year fixed effects & Yes & Yes & Yes & Yes & Yes & Yes \\
\hline Industry fixed effects & Yes & Yes & Yes & Yes & Yes & Yes \\
\hline County fixed effects & No & No & Yes & No & No & Yes \\
\hline No. of obs. & 31,757 & 31,757 & 31,757 & 31,757 & 31,757 & 31,757 \\
\hline Adj. $R^{2}$ & 0.41 & 0.42 & 0.51 & 0.25 & 0.27 & 0.31 \\
\hline
\end{tabular}

impact or influence of those inventions. For each dependent variable, three specifications are used. In the first specification, the full set of firm-specific controls is included together with year and industry fixed effects. In the second specification, county demographic controls are included in addition to the controls from specification (1). Finally, in the third specification, county fixed effects are 
included in addition to industry and year fixed effects. Again, we exclude all variables measured at the county level in the county fixed effects regression to be consistent with Kumar et al. (2011). In all regressions, a control for lagged R\&D expenditure is included. This variable captures the increase in innovative output that occurs as a consequence of increased $R \& D$ expenditure over the preceding years. The coefficient estimate on $\ln (\mathrm{CP}$ ratio), therefore, captures the impact that gambling attitudes have on innovative outcomes that are independent of R\&D spending. Standard errors are clustered at the firm level across all regressions.

In columns (1) and (2) of Table 4, the dependent variable is the natural logarithm of 1 plus patent count. The coefficient estimate on $\ln (\mathrm{CP}$ ratio) is positive and significant across both model specifications. In the more robust specification (column (2)), the coefficient estimate on $\ln (\mathrm{CP}$ ratio) is 0.07 and significant at the $5 \%$ level. This means that a 1 -standard-deviation increase in $\ln (\mathrm{CP}$ ratio) is associated with an increase of $\ln (1+$ patent count $)$ of 0.0399 . Relative to the unconditional mean of $\ln (1+$ patent count $)$ reported in Table 1 of 0.47 , this represents an increase of approximately $8 \%$. The results do not change qualitatively in column (3) where county fixed effects are included.

Predictably, the coefficient estimate on R\&D capital is positive and highly significant. Larger firms, capital-intensive firms, firms with growth opportunities, and firms with large cash reserves are better at generating innovative inventions. Consistent with Aghion et al. (2013), we find that innovative output increases with institutional ownership. Analyst following is positively related with patent count, while product market competition is negatively related with innovative output. ${ }^{14}$ In terms of the county demographic characteristics, we observe a strong negative relation between the level of religiosity and output.

The dependent variable in columns (4) and (5) of Table 4 is the natural logarithm of 1 plus citations per patent. The coefficient estimate on $\ln (\mathrm{CP}$ ratio) is positive and significant at the $1 \%$ level. In the more robust model specification where all control variables are included (column (5)), the coefficient estimate on $\ln (\mathrm{CP}$ ratio $)$ is 0.07 . This means that a 1 -standard-deviation increase in $\ln (\mathrm{CP}$ ratio $)$ is associated with an increase of $0.0399 \mathrm{in} \ln (1+$ citations per patent). Relative to the mean $\ln (1+$ citations per patent $)$ of 0.33 reported in Table 1 , this represents an increase of over $12 \%$. In column (6), the inclusion of county fixed effects does not alter the sign of the $\mathrm{CP}$ ratio, although the statistical significance is reduced.

The coefficient estimates on the remaining control variables are largely consistent with the results reported for regressions (1)-(3). Larger, more capitalintensive, and cash-rich firms achieve greater innovative success. Institutional ownership and analyst following also enhance the significance of innovative output, while product market competition is negatively related with $\ln (1+$ citations per patent).

\footnotetext{
${ }^{14} \mathrm{He}$ and Tian (2013) report a negative relation between analyst following and innovative activity, while we find a positive relation. Nevertheless, our results can be reconciled with theirs, as He and Tian include firm fixed effects in all regressions, while we only include industry and year fixed effects. In the regressions where firm fixed effects are not included, He and Tian also observe a positive relation between analyst following and innovation.
} 
Taken together, the results reported in Table 4 show that firms located in counties with a greater predisposition to gamble achieve better innovative outcomes even after accounting for the funds invested in $R \& D$ over the previous years.

\section{Robustness Checks}

In this section we check the robustness of our results and address the endogeneity issue. We divide our discussion into two subsections. In the first subsection, we perform general robustness tests. In the second subsection, we address the potential omitted variable bias as well as the conceivable reverse causality problem associated with our results. Robustness tests are reported in Table 5, which presents the coefficient estimates and $t$-statistics on the variable of interest, $\ln (\mathrm{CP}$ ratio), together with the number of observations in different specifications. Three sets of regression tests are reported. In the first set, the dependent variable is $\mathrm{R} \& \mathrm{D} /$ Assets; in the second, the dependent variable is $\ln (1+$ patent count $)$; and in the third, the dependent variable is $\ln (1+$ citations per patent $)$. The tests are based on the regression model from Tables 3 and 4, where the full set of controls

\section{TABLE 5}

\section{Robustness Checks}

Table 5 reports the results of several robustness tests performed on the regressions of R\&D/Assets, In( $1+$ Patent count), and $\ln (1+$ Citations per patent). The main specification shows the estimate from the regression on the full sample as reported in column (3) in Table 3, and columns (2) and (5) in Table 4. For brevity, the table only reports the coefficients on the CP ratio. Unless otherwise stipulated, the regressions include year and industry fixed effects, defined based on 2 -digit $\mathrm{SIC}$ codes, and standard errors are corrected for clustering of observations at the firm level.

Main Specification

General Robustness

(1) CP ratio instead of In(CP ratio)

(2) Control for firm age

(3) Sample including only survey year

(4) Exclude 2005 and 2006 from sample

(5) Exclude firm-years where patent count is 0

(6) Fama-MacBeth regression

(7) Include industry cluster control

(8) Double-cluster standard errors by firm and county

Addressing Omitted Variables Bias and Reverse Causality

(9) Include state-level business $0.006 \quad 2.11 \quad 31,757$ environment controls

(10) Control for corporate governance

(11) Control for CEO incentives

(12) 2SLS with lagged CP ratio as instrument

(13) Exclude 5 most and least CP ratio counties

(14) Exclude 10 largest counties

(15) Exclude Silicon Valley firms
Dependent Variable

\begin{tabular}{|c|c|c|c|c|c|c|c|c|}
\hline \multicolumn{3}{|c|}{ R\&D/Assets } & \multicolumn{3}{|c|}{ In(1 + Patent count $)$} & \multicolumn{3}{|c|}{ In(1+Citations per patent) } \\
\hline Coeff. & $t$-Stat. & $\begin{array}{l}\text { No. of } \\
\text { Obs. }\end{array}$ & Coeff. & t-Stat. & $\begin{array}{l}\text { No. of } \\
\text { Obs. }\end{array}$ & Coeff. & t-Stat. & $\begin{array}{c}\text { No. of } \\
\text { Obs. }\end{array}$ \\
\hline 0.01 & 4.44 & 31,757 & 0.07 & 2.79 & 31,757 & 0.07 & 4.54 & 31,757 \\
\hline 0.003 & 3.72 & 31,757 & 0.02 & 2.45 & 31,757 & 0.02 & 3.66 & 31,757 \\
\hline 0.009 & 3.57 & 31,757 & 0.07 & 2.75 & 31,757 & 0.09 & 5.01 & 31,757 \\
\hline 0.008 & 3.12 & 2,756 & 0.14 & 2.34 & 2,756 & 0.05 & 2.01 & 2,756 \\
\hline 0.01 & 3.56 & 28,593 & 0.06 & 2.57 & 28,593 & 0.08 & 4.35 & 28,593 \\
\hline 0.01 & 2.14 & 9,099 & 0.12 & 2.87 & 9,099 & 0.09 & 2.53 & 9,099 \\
\hline 0.009 & 1.74 & 31,757 & 0.16 & 3.25 & 31,757 & 0.11 & 2.45 & 31,757 \\
\hline 0.009 & 3.53 & 31,757 & 0.07 & 2.64 & 31,757 & 0.12 & 4.23 & 31,757 \\
\hline 0.01 & 3.97 & 31,757 & 0.09 & 2.18 & 31,757 & 0.11 & 4.12 & 31,757 \\
\hline \multicolumn{9}{|c|}{ d Reverse Causality } \\
\hline 0.006 & 2.11 & 31,757 & 0.06 & 2.55 & 31,757 & 0.05 & 2.57 & 31,757 \\
\hline 0.009 & 3.50 & 7,522 & 0.15 & 3.30 & 7,522 & 0.07 & 2.59 & 7,522 \\
\hline 0.006 & 5.09 & 12,115 & 0.03 & 2.14 & 12,115 & 0.03 & 2.94 & 12,115 \\
\hline 0.009 & 3.74 & 31,093 & 0.11 & 2.19 & 31,093 & 0.13 & 6.59 & 31,093 \\
\hline 0.009 & 3.58 & 31,124 & 0.10 & 3.14 & 31,124 & 0.13 & 6.32 & 31,124 \\
\hline 0.007 & 2.43 & 23,627 & 0.06 & 2.69 & 23,627 & 0.05 & 3.28 & 23,627 \\
\hline 0.005 & 2.29 & 27,631 & 0.09 & 4.64 & 27,631 & 0.10 & 5.42 & 27,631 \\
\hline
\end{tabular}


are included together with industry and year fixed effects. All standard errors are clustered at the firm level.

\section{General Robustness}

In the first subsection, we perform different tests to evaluate the robustness of our main findings. In row (1) of Table 5 we show that the results do not materially change when we use the $\mathrm{CP}$ ratio instead of $\ln (\mathrm{CP}$ ratio). The relation between social gambling preferences and $\mathrm{R} \& \mathrm{D}$ expenditure remains positive and statistically significant, as does the relation between gambling preferences and innovative output. In row (2) we control for the natural logarithm of firm age because younger firms are presumably more innovative than mature firms. If certain counties have clusters of young firms, this could bias our results. We find that controlling for firm size does not alter the results.

In row (3) of Table 5 we consider a reduced sample that includes only the survey years $(1980,1990,2000)$. The religion-based proxy, which is used throughout this paper, is obtained after linearly interpolating religious adherence rates in the three survey years. Concentrating only on the survey year ensures that we rely only on actual data, rather than projected data, thus overcoming the look-ahead bias that is associated with linear interpolation. We find that the results are consistent with the baseline results even in this reduced sample.

In row (4) of Table 5 we exclude the years 2005 and 2006 from our sample. Although patent data are available until 2006, Hall et al. (2001) suggest ending the sample 2 years early to avoid time truncation issues arising from the fact that it takes 2 years on average for a patent application to be granted. We find that eliminating the final 2 years of the sample does not alter our results.

Perhaps a greater concern is the large number of firms in our sample that have zero patents. This raises the possibility that our results are driven by a jump from zero patents to a positive number. To deal with this potential problem, in row (5) we exclude from our sample those firms with zero patents (and therefore zero citations). This reduces the sample to 9,099. We find that our results are consistent with the baseline results. In fact, the coefficients substantially increase in this more restricted sample.

Another potential concern is that there might be a time-series trend between the $\mathrm{CP}$ ratio and innovation. For example, there might be an upward trend in the $\mathrm{CP}$ ratio and $\mathrm{R} \& \mathrm{D}$ (or innovative output) over the sample period without any causal relation. To overcome this problem, we run a Fama-MacBeth (1973) regression in row (6) of Table 5 that is a pure cross-sectional regression unaffected by time-series trends. We find that the results of the Fama-MacBeth regression are consistent with the ordinary least squares (OLS) results.

In row (7) of Table 5 we include an industry cluster dummy to control for those industries that cluster in specific counties. Specifically, for each industry and year, we code as one the top 10 counties with the highest clusters of a particular industry (measured by sales). We find that controlling for industry clusters does not alter the results. In row (8) we address the possibility that the decisions of different firms in a county are correlated. We do so by repeating our baseline regression model but this time replace standard errors clustered at the firm level with standard errors double-clustered by firm and county. This reduces the 
$t$-statistics relative to the baseline results, but our results nevertheless stay quantitatively unchanged.

\section{Omitted Variable and Reverse Causality}

Despite the fact that our baseline regressions utilize a large number of firm and county controls (and county fixed effects), there remains the possibility that omitted variables correlated with the $\mathrm{CP}$ ratio are driving our results. This subsection deals with those issues. In row (9) of Table 5 we include controls for the economic and regulatory environment of a state. We obtain this data from the Forbes Web page (www.forbes.com). The economic and regulatory controls include business activity rank, labor supply rank, regulatory environment rank, economic climate rank, and growth prospect rank. We include these controls, as it is possible that the environmental and economic environment of a state can play a large role in attracting capital necessary to undertake research projects. Nevertheless, we find that the inclusion of the state-level controls does not alter our results.

In row (10) of Table 5 we control for corporate governance factors. In particular, we control for anti-takeover provisions, measured by the governance index developed by Gompers, Ishii, and Metrick (2003), the percentage of shares owned by the top five directors, and whether the CEO and chairman of the board are the same person. It is possible that firms located in areas with higher CP ratios have greater corporate governance control, which results in better innovative outcomes. Although such a possibility is not inconsistent with our argument, we find that the results stay unchanged after controlling for corporate governance quality.

In row (11) of Table 5 we control for CEO incentives, as measured by stock option delta and vega. As discussed in greater detail in Section II.D, delta measures the sensitivity of CEO stock options to a change in the value of the underlying stock, while vega measures the sensitivity of CEO stock options to the underlying volatility. It is possible that firms located in areas with higher CP ratios offer more options to their managers, which may be driving our results. Again, this explanation is not necessarily inconsistent with our broad argument that social gambling propensity creates a business environment that is friendly toward innovation. Nevertheless, we find that our results are unchanged after controlling for CEO option incentives.

There are two potential interpretations of the positive link between the $\mathrm{CP}$ ratio and innovative activity. The first is that firms that are located in more gambling-prone areas invest more in innovation and generate greater innovative output. The second interpretation is that firms that have greater innovative needs locate in more gambling-prone areas. We address this reverse causality problem in tests (12)-(14).

In row (12) of Table 5 we run a two-stage least squares (2SLS) model by using the 3 -year lagged value of $\ln (\mathrm{CP}$ ratio) as an instrument for $\ln (\mathrm{CP}$ ratio). This approach is consistent with Hilary and Hui (2009) and Kumar et al. (2011), and it mitigates the issue of causality and omitted variables bias. The results from the 2SLS regression are consistent with the baseline results, with the coefficient estimates being stronger in magnitude.

Furthermore, in row (13) of Table 5 we exclude the five counties with the highest and lowest $\mathrm{CP}$ ratio scores. If firms were to choose the location of their 
headquarters based on their innovative needs, it would make sense for innovative firms to flock to the areas with the highest preferences toward gambling. Excluding firms located in counties with the highest and lowest $\mathrm{CP}$ ratios therefore ensures that extreme counties do not bias our results. We find that our results stay unchanged in this more restrictive sample.

Finally, in rows (14) and (15) of Table 5, to further address the issue of spurious correlation we exclude the 10 largest counties (ranked by population) and firms located in Silicon Valley, respectively. This test ensures that our results are not driven by a clustering of Catholics in large counties or a clustering of high tech firms in Catholic areas. The results do not change qualitatively after restricting the sample.

It is ultimately impossible to completely overcome endogeneity in our (or any) empirical design. Nevertheless, the results presented in this subsection suggest a causal relation between social gambling preferences and corporate innovation. Furthermore, a firm's decision of where to locate its headquarters is affected by a number of factors, with innovative needs playing only a minor role. Overall, we believe that our results suggest a strong positive association between local gambling preferences and innovative activity.

\section{Social Gambling Preferences and CEO Overconfidence}

Two recent papers identify a behavioral aspect of innovation. Galasso and Simcoe (2011) and Hirshleifer et al. (2012) find a positive influence of CEO overconfidence on innovation. In this section, we examine the interaction between CEO overconfidence and social gambling preferences. While socially induced appetite for gambling affects behavior differently from CEO overconfidence, both forms of behavior help in overcoming the disincentives to innovate (brought on by large probabilities of failure and the long-term nature of innovative programs). We specifically examine the interplay between CEO overconfidence and gambling preferences in affecting innovative activity. This analysis helps us gauge whether single-person behavioral traits are more relevant for innovation than communitywide behavioral traits, or vice versa.

\section{A. Full Sample}

In Table 6 we report regressions of innovative activity (R\&D/Assets, patent count, citations per patent) on social gambling preferences and CEO overconfidence. Consistent with the extant literature, we utilize two proxies of CEO overconfidence. The first is an option-based measure denoted Holder 67, which is an indicator variable equal to 1 for those years where the CEO holds options that are over $67 \%$ in the money. The second proxy of overconfidence is a press-based measure denoted Confident, which is an indicator variable equal to 1 for those years where the number of articles referring to the CEO as "confident" in Factiva exceeds the number of articles referring to the CEO as "cautious." For each dependent variable, we use two specifications: one in which we include $\ln (\mathrm{CP}$ ratio) and $\mathrm{CEO}$ overconfidence as the main variables of interest, and the other where we interact $\ln (\mathrm{CP}$ ratio) with $\mathrm{CEO}$ overconfidence. 
TABLE 6

\section{Gambling Preferences and CEO Overconfidence}

Table 6 reports the regression results of the interplay between gambling preferences and CEO overconfidence. The results are presented in two panels. In Panel A, the measure of CEO overconfidence is based on executive stock options and denoted as Holder 67 . Holder 67 is an indicator variable equal to 1 for all years where the CEO holds options that are at least $67 \%$ in the money. In Panel B, the measure of CEO overconfidence is a press-based measure denoted as Confident. Confident is an indicator variable equal to 1 when the number of "confident" articles for a CEO in Factiva exceeds the number of "cautious" articles. All independent variables are lagged by 1 year. All regressions include year and industry fixed effects, defined based on 2-digit SIC codes. Intercepts are not reported. Standard errors are corrected for clustering of observations at the firm level (t-statistics in parentheses); ${ }^{*},{ }^{\star \star}$, and ${ }^{\star \star \star}$ measure significance at the $10 \%, 5 \%$, and $1 \%$ levels, respectively; and variable definitions are provided in the Appendix.

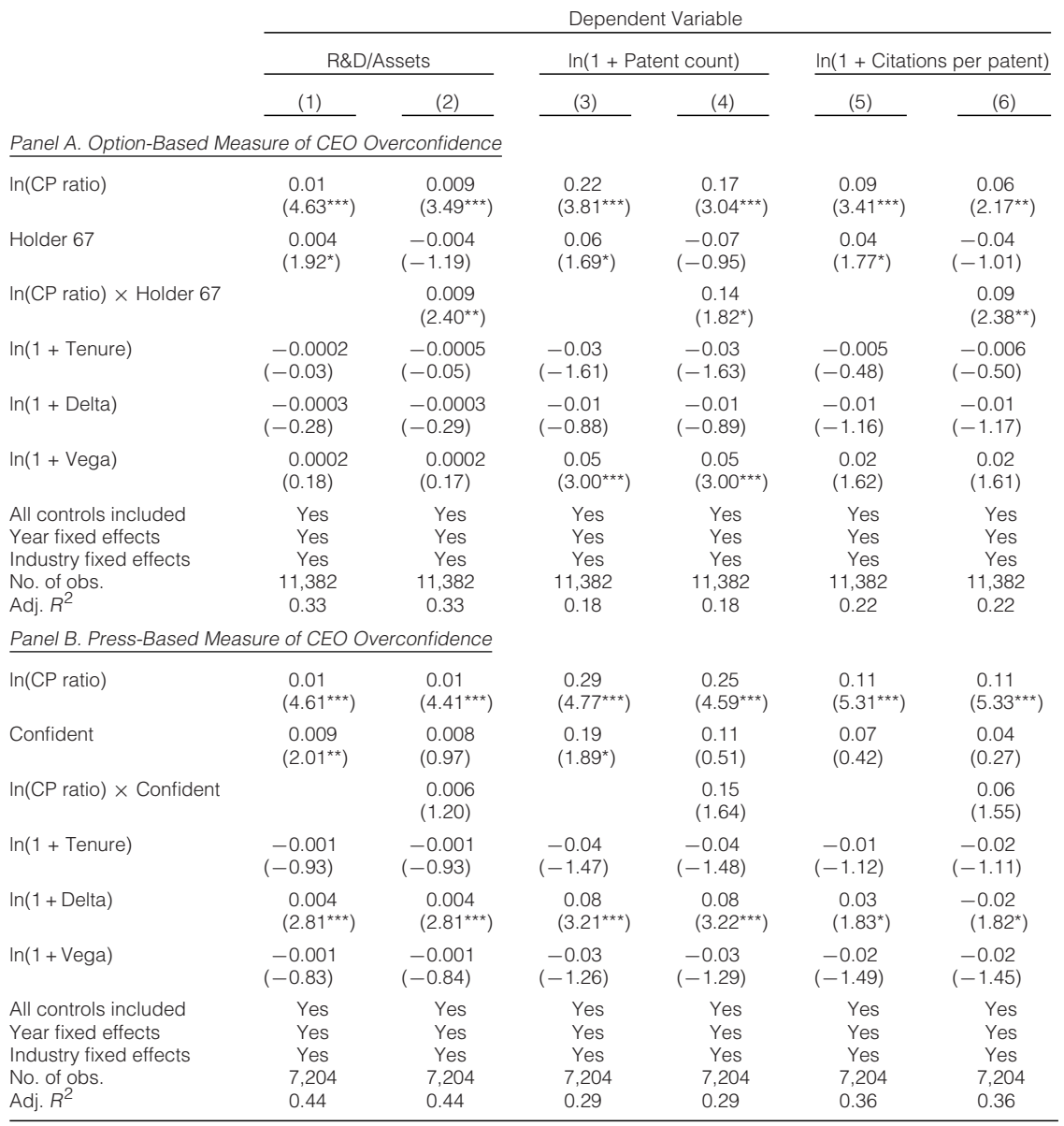

Results utilizing Holder 67 as the proxy of overconfidence are reported in Panel A, while results based on the press-based proxy of overconfidence are reported in Panel B.

Consistent with Hirshleifer et al. (2012), across all regressions we control for CEO tenure and incentives (delta and vega). In the process of controlling for CEO overconfidence and other CEO characteristics, we also address the issue of omitted variables. For example, it is feasible that the results reported up to this 
point are merely driven by $\mathrm{CEO}$-specific factors being related to our proxy of social gambling preferences. In turn, the interaction term shows whether social gambling preferences are relevant to the way that CEOs express their level of overconfidence. All regressions include the full set of firm and demographic controls as well as year and industry fixed effects. Standard errors are clustered at the firm level.

In column (1) of Panel A of Table 6, we find that the coefficient estimate on $\ln (\mathrm{CP}$ ratio) retains its economic and statistical significance after controlling for $\mathrm{CEO}$ overconfidence. In fact, the statistical significance of $\ln (\mathrm{CP}$ ratio) increases relative to the baseline results. In turn, the coefficient estimate on the Holder 67 variable is considerably weaker than that reported in Hirshleifer et al. (2012). ${ }^{15}$ This suggests that controlling for social gambling preferences significantly diminishes the impact of CEO overconfidence on R\&D expenditure. In column (2), the coefficient estimate on the Holder 67 variable is statistically insignificant, suggesting that CEO overconfidence has little effect on R\&D expenditure when the firm is located in a county with low gambling preferences. The interaction term is positive and statistically significant at the $5 \%$ level. This finding shows that CEO overconfidence has a more pronounced effect on innovative spending in firms that are located in high CP ratio areas. Local norms, which influence corporate culture, clearly have a significant impact on whether CEO overconfidence is reflected in corporate decision making.

In column (3) of Panel A of Table 6 we observe the link between $\ln (\mathrm{CP}$ ratio) and $\ln (1+$ patent count $)$ after controlling for CEO characteristics. The coefficient estimate on $\ln (\mathrm{CP}$ ratio) increases in statistical and economic significance relative to the baseline regressions. Once again, this finding shows that local gambling preferences have a robust effect on innovative output, even after controlling for CEO characteristics. The coefficient estimate on Holder 67 is positive and significant at the $10 \%$ level, although the magnitude of the coefficient estimate and statistical significance are considerably weaker compared with the results reported in Hirshleifer et al. (2012). The coefficient estimate on the Holder 67 variable becomes insignificant when the interaction term is added in column (4). The fact that the coefficient estimate on the Holder 67 variable becomes statistically insignificant in the regressions with interaction terms suggests that CEO overconfidence has little impact on innovative activity when gambling preferences are low. The interaction term reported in column (4) is positive and statistically significant at the $10 \%$ level, which shows that overconfident CEOs have a positive effect on innovative output only when the firm is more susceptible to gambling behavior.

Similar results are observed in columns (5) and (6) of Table 6. The coefficient estimate on $\ln (\mathrm{CP}$ ratio) retains its economic and statistical significance after controlling for CEO characteristics. The coefficient estimate on the interaction term between $\ln (\mathrm{CP}$ ratio) and Holder 67 is also positive and statistically significant. Taken together, these results show that locally induced gambling preferences have

\footnotetext{
${ }^{15}$ In unreported results, we find that Holder 67 is positively and significantly related to our measures of innovative activity when we exclude $\ln (\mathrm{CP}$ ratio) from our analysis. This shows that social gambling preferences reduce the explanatory power of CEO overconfidence.
} 
a more pronounced effect on innovative activity than CEO overconfidence. Furthermore, whether CEO overconfidence is a relevant factor in affecting innovative activity is largely determined by the cultural norms pertaining to gambling preferences in the area where they work.

The results in Panel B of Table 6, which are based on the press-based measure of CEO overconfidence, are largely consistent with the results reported in Panel A. The coefficient estimate on $\ln (\mathrm{CP}$ ratio) increases in magnitude relative to the baseline results presented throughout this paper after controlling for CEO overconfidence. Furthermore, the coefficient estimate on the CEO overconfidence variable becomes statistically insignificant after including the interaction term in the regression model. Although the coefficient estimates on the interaction terms are statistically insignificant, they are all positive and close to significance at the $10 \%$ level. Once again, this demonstrates that CEO overconfidence has little effect on innovative activity when gambling preferences are low.

\section{B. Effect across Industries}

Hirshleifer et al. (2012) show that overconfident CEOs primarily affect innovative outcomes in innovative industries. For this reason we concentrate on the interplay between social gambling preferences and CEO overconfidence across innovative and noninnovative industries in Table 7. The variables of interest in Table 7 are the interaction terms, which tell us whether the interaction between CEO overconfidence and innovative activity is conditioned by local norms pertaining to gambling preferences. We divide Table 7 into two panels. The results in Panel A are based on the option-based measure of CEO overconfidence, while the results in Panel B are based on the press-based measure of overconfidence.

In columns (1) and (2) of Panel A of Table 7, the dependent variable is R\&D scaled by assets. In the innovative industry subsample the coefficient estimate on the interaction term is positive and statistically significant at the $10 \%$ level. In contrast, the coefficient estimate is not statistically different from 0 in the noninnovative industry subsample. In both subsamples the coefficient estimates on Holder 67 are not statistically significant. These results mean that CEO overconfidence only influences innovative spending in innovative industries, and in those firms that are located in areas that are more susceptible to gambling preferences. The finding that CEO overconfidence has a strong effect in innovative industries is consistent with that of Hirshleifer et al. (2012). However, our finding, that the local norms surrounding the firm in which CEOs work have a very strong bearing on how overconfidence manifests itself, is entirely new.

Innovative outputs are insignificantly affected by CEO overconfidence in both innovative and noninnovative industries, with the interaction term also being insignificant. However, in the regressions where the dependent variable is citations per patent (columns (5) and (6) of Table 7) the coefficient estimate on the interaction term for the innovative industry subsample is positive and significant at the $10 \%$ level. In the noninnovative industry subsample, the interaction term is insignificant.

The results reported in Panel B of Table 7 and based on the press-based measure are consistent with those reported in Panel A. The interaction terms between 
TABLE 7

Gambling Preferences, CEO Overconfidence, and Industry Type

Table 7 reports the regression results of the interplay between gambling preferences and CEO overconfidence across innovative and noninnovative industries. An innovative industry is defined as one whose citations-per-patent count is above the cross-sectional median over the sample period. The results are presented in two panels. In Panel A, the measure of CEO overconfidence is based on executive stock options and denoted as Holder 67 . Holder 67 is an indicator variable equal to 1 for all years where the CEO holds options that are at least $67 \%$ in the money. In Panel B, the measure of CEO overconfidence is a press-based measure denoted as Confident. Confident is an indicator variable equal to 1 when the number of "confident" articles for a CEO in Factiva exceeds the number of "cautious" articles. All independent variables are lagged by 1 year. All regressions include year and industry fixed effects, defined based on 2-digit SIC codes. Intercepts are not reported. Standard errors are corrected for clustering of observations at the firm level ( $t$-statistics in parentheses) ${ }^{\star},{ }^{* \star}$, and ${ }^{\star \star \star}$ measure significance at the $10 \%, 5 \%$, and $1 \%$ levels, respectively; and variable definitions are provided in the Appendix.

\begin{tabular}{|c|c|c|c|c|c|}
\hline \multicolumn{2}{|c|}{ R\&D/Assets } & \multicolumn{2}{|c|}{$\ln (1+$ Patent count $)$} & \multicolumn{2}{|c|}{$\ln (1+$ Citations per patent $)$} \\
\hline $\begin{array}{l}\text { Innovative } \\
\text { Industry }\end{array}$ & $\begin{array}{l}\text { Noninnovative } \\
\text { Industry }\end{array}$ & $\begin{array}{l}\text { Innovative } \\
\text { Industry }\end{array}$ & $\begin{array}{l}\text { Noninnovative } \\
\text { Industry }\end{array}$ & $\begin{array}{l}\text { Innovative } \\
\text { Industry }\end{array}$ & $\begin{array}{l}\text { Noninnovative } \\
\text { Industry }\end{array}$ \\
\hline (1) & (2) & (3) & (4) & (5) & (6) \\
\hline
\end{tabular}

Panel A. Option-Based Measure of CEO Overconfidence

\begin{tabular}{|c|c|c|c|c|c|c|}
\hline In(CP ratio) & $\begin{array}{c}0.009 \\
\left(2.65^{\star * *}\right)\end{array}$ & $\begin{array}{l}0.01 \\
\left(2.60^{* * *}\right)\end{array}$ & $\begin{array}{c}0.02 \\
(1.52)\end{array}$ & $\begin{array}{l}0.08 \\
\left(2.71^{* * *}\right)\end{array}$ & $\begin{array}{l}0.11 \\
\left(2.45^{\star *}\right)\end{array}$ & $\begin{array}{c}0.23 \\
\left(3.57^{\star * *}\right)\end{array}$ \\
\hline Holder 67 & $\begin{array}{l}-0.002 \\
(-0.53)\end{array}$ & $\begin{array}{c}0.004 \\
(0.83)\end{array}$ & $\begin{array}{l}-0.05 \\
(-0.48)\end{array}$ & $\begin{array}{c}0.04 \\
(0.35)\end{array}$ & $\begin{array}{c}-0.05 \\
(-0.85)\end{array}$ & $\begin{array}{c}0.03 \\
(0.47)\end{array}$ \\
\hline $\ln (\mathrm{CP}$ ratio $) \times$ Holder 67 & $\begin{array}{c}0.007 \\
\left(1.75^{*}\right)\end{array}$ & $\begin{array}{l}-0.005 \\
(-0.87)\end{array}$ & $\begin{array}{c}0.08 \\
(0.80)\end{array}$ & $\begin{array}{c}0.06 \\
(0.53)\end{array}$ & $\begin{array}{c}0.09 \\
\left(1.89^{\star}\right)\end{array}$ & $\begin{array}{c}0.02 \\
(0.30)\end{array}$ \\
\hline $\ln (1+$ Tenure $)$ & $\begin{array}{l}0.0002 \\
(0.22)\end{array}$ & $\begin{array}{l}-0.002 \\
\left(-1.67^{\star}\right)\end{array}$ & $\begin{array}{l}-0.02 \\
(-0.55)\end{array}$ & $\begin{array}{l}-0.08 \\
\left(-2.33^{\star \star}\right)\end{array}$ & $\begin{array}{c}0.002 \\
(0.16)\end{array}$ & $\begin{array}{l}-0.02 \\
(-0.87)\end{array}$ \\
\hline $\ln (1+$ Delta $)$ & $\begin{array}{c}-0.003 \\
\left(-2.28^{\star \star}\right)\end{array}$ & $\begin{array}{l}-0.0009 \\
(-0.71)\end{array}$ & $\begin{array}{c}-0.04 \\
\left(-1.95^{\star}\right)\end{array}$ & $\begin{array}{l}-0.04 \\
\left(-1.69^{\star}\right)\end{array}$ & $\begin{array}{l}-0.04 \\
\left(-3.01^{\star \star \star}\right)\end{array}$ & $\begin{array}{l}-0.02 \\
(-0.86)\end{array}$ \\
\hline $\ln (1+$ Vega $)$ & $\begin{array}{c}0.006 \\
\left(4.09^{* \star *}\right)\end{array}$ & $\begin{array}{c}0.001 \\
(0.66)\end{array}$ & $\begin{array}{l}0.11 \\
\left(4.21^{\star \star \star}\right)\end{array}$ & $\begin{array}{l}0.06 \\
\left(2.11^{\star *}\right)\end{array}$ & $\begin{array}{l}0.06 \\
\left(3.89^{* * *}\right)\end{array}$ & $\begin{array}{c}0.004 \\
(0.23)\end{array}$ \\
\hline $\begin{array}{l}\text { All controls included } \\
\text { Year fixed effects } \\
\text { Industry fixed effects } \\
\text { No. of obs. } \\
\text { Adj. } R^{2}\end{array}$ & $\begin{array}{l}\text { Yes } \\
\text { Yes } \\
\text { Yes } \\
7,195 \\
0.42\end{array}$ & $\begin{array}{l}\text { Yes } \\
\text { Yes } \\
\text { Yes } \\
4,187 \\
0.42\end{array}$ & $\begin{array}{l}\text { Yes } \\
\text { Yes } \\
\text { Yes } \\
7,195 \\
0.22\end{array}$ & $\begin{array}{l}\text { Yes } \\
\text { Yes } \\
\text { Yes } \\
4,187 \\
0.27\end{array}$ & $\begin{array}{l}\text { Yes } \\
\text { Yes } \\
\text { Yes } \\
7,195 \\
0.29\end{array}$ & $\begin{array}{l}\text { Yes } \\
\text { Yes } \\
\text { Yes } \\
4,187 \\
0.28\end{array}$ \\
\hline \multicolumn{7}{|c|}{ Panel B. Press-Based Measure of CEO Overconfidence } \\
\hline In(CP ratio) & $\begin{array}{l}0.02 \\
\left(3.19^{\star \star *}\right)\end{array}$ & $\begin{array}{l}0.02 \\
\left(3.91^{\star \star *}\right)\end{array}$ & $\begin{array}{l}0.32 \\
\left(2.65^{\star \star *}\right)\end{array}$ & $\begin{array}{l}0.67 \\
\left(4.07^{\star \star *}\right)\end{array}$ & $\begin{array}{l}0.20 \\
\left(3.10^{\star * *}\right)\end{array}$ & $\begin{array}{l}0.36 \\
\left(4.63^{\star \star *}\right)\end{array}$ \\
\hline Confident & $\begin{array}{l}-0.005 \\
(-0.81)\end{array}$ & $\begin{array}{c}0.03 \\
(1.49)\end{array}$ & $\begin{array}{l}-0.01 \\
(-0.12)\end{array}$ & $\begin{array}{c}0.38 \\
(0.94)\end{array}$ & $\begin{array}{c}0.24 \\
\left(1.77^{\star}\right)\end{array}$ & $\begin{array}{c}0.06 \\
(0.91)\end{array}$ \\
\hline $\ln (\mathrm{CP}$ ratio $) \times$ Confident & $\begin{array}{l}0.01 \\
\left(1.75^{\star}\right)\end{array}$ & $\begin{array}{l}-0.01 \\
(-0.91)\end{array}$ & $\begin{array}{c}0.25 \\
(1.55)\end{array}$ & $\begin{array}{l}-0.13 \\
(-0.39)\end{array}$ & $\begin{array}{c}0.20 \\
\left(1.74^{\star}\right)\end{array}$ & $\begin{array}{l}-0.005 \\
(-0.07)\end{array}$ \\
\hline $\ln (1+$ Tenure $)$ & $\begin{array}{l}0.0007 \\
(0.46)\end{array}$ & $\begin{array}{l}-0.003 \\
(-1.62)\end{array}$ & $\begin{array}{l}-0.01 \\
(-0.31)\end{array}$ & $\begin{array}{l}-0.09 \\
\left(-1.98^{\star \star}\right)\end{array}$ & $\begin{array}{l}-0.006 \\
(-0.35)\end{array}$ & $\begin{array}{c}-0.03 \\
(-1.22)\end{array}$ \\
\hline $\ln (1+$ Delta $)$ & $\begin{array}{l}0.008 \\
\left(3.76^{\star \star \star}\right)\end{array}$ & $\begin{array}{l}0.0009 \\
(0.48)\end{array}$ & $\begin{array}{l}0.11 \\
\left(3.50^{\star \star \star}\right)\end{array}$ & $\begin{array}{c}0.01 \\
(0.28)\end{array}$ & $\begin{array}{l}0.05 \\
\left(2.96^{\star \star \star}\right)\end{array}$ & $\begin{array}{c}-0.02 \\
(-0.71)\end{array}$ \\
\hline $\ln (1+$ Vega $)$ & $\begin{array}{c}-0.004 \\
\left(-1.89^{*}\right)\end{array}$ & $\begin{array}{l}0.0005 \\
(0.04)\end{array}$ & $\begin{array}{c}-0.04 \\
(-1.39)\end{array}$ & $\begin{array}{l}-0.01 \\
(-0.32)\end{array}$ & $\begin{array}{l}-0.04 \\
\left(-2.22^{\star \star}\right)\end{array}$ & $\begin{array}{c}0.005 \\
(0.22)\end{array}$ \\
\hline All controls included & Yes & Yes & Yes & Yes & Yes & Yes \\
\hline Year fixed effects & Yes & Yes & Yes & Yes & Yes & Yes \\
\hline Industry fixed effects & Yes & Yes & Yes & Yes & Yes & Yes \\
\hline No. of obs. & 4,616 & 2,588 & 4,616 & 2,588 & 4,616 & 2,588 \\
\hline Adj. $R^{2}$ & 0.45 & 0.50 & 0.26 & 0.38 & 0.36 & 0.39 \\
\hline
\end{tabular}

local gambling preferences and CEO overconfidence tend to be positive and significant for firms in innovative industries and insignificant for firms in noninnovative industries.

The results presented in Tables 6 and 7 highlight the fact that while CEO overconfidence is relevant to innovative activity, it is only relevant in innovative industries, and for firms that are already preconditioned toward gambling 
behavior. Perhaps more significantly, the results suggest that local norms surrounding corporate headquarters are a more relevant factor in determining innovative activity than the personal traits of top executives.

\section{Conclusion}

Corporate innovation is an essential element of a thriving economy. Understanding what factors drive innovation is therefore critically important. While numerous recent studies have dealt with the rational factors that influence innovative activity, the role of human behavior in driving innovation has attracted far less attention. With the central role of the individual in the innovating process, it is difficult to argue that the way people behave and the preferences they have do not influence innovative outcomes. We address this issue by relating religion-induced attitudes toward gambling with innovative outcomes.

Using a religion-based proxy of social gambling preferences, we find that firms headquartered in counties where gambling propensity is high tend to undertake riskier projects and spend more on innovation. These firms also achieve higher innovative output, as measured by the volume of patents and the citations that these patents generate. Our results are robust to a large number of alternative specifications and endogeneity concerns.

The positive effect that social gambling preferences have on innovative activity demonstrated in this study has certain similarities with the findings in Galasso and Simcoe (2011) and Hirshleifer et al. (2012) with regard to a positive relation between $\mathrm{CEO}$ overconfidence and corporate innovation. The most revealing findings are that local gambling preferences are a stronger determinant of innovative activity and that overconfident CEOs are more effective in innovative outcomes when they work in areas that have a strong preference for gambling. This is primarily the case for firms in innovative industries. Our results show that not only are social gambling preferences a stronger determinant of innovative outcomes than CEO overconfidence, but the influence that CEO overconfidence has on corporate decision making is largely conditioned on the social norms where they work.

Taken together, our results show that social attitudes surrounding corporate headquarters have a nontrivial effect on corporate innovative outcomes. Our results warrant further work on the interplay between corporate governance structures and local gambling preferences in affecting corporate innovation.

\section{Appendix. Variable Definition and Sources}

This Appendix defines the variables used in the study. We obtain the patent data from the NBER Patent database, religion variables from ARDA, accounting data from Compustat, stock returns data from CRSP, county demographic data from the U.S. Census Bureau, and CEO-specific data from ExecuComp.

Dependent Variable

R\&D/Assets: Research and development expenditure scaled by book assets. Missing values coded with 0 .

Patent count: Number of patents applied for during the year. 
Citations per patent: Total number of citations summed across all patent's applied for during the year. Each patent's number of citations is multiplied by the weighting index from Hall et al. (2005).

\section{County-Level Explanatory Variables}

$\mathrm{CP}$ ratio: The ratio of Catholic residents over Protestant residents in the county where the firm is headquartered.

Religiosity: The portion of a county's population whose residents adhere to any religion in the county where the firm is headquartered.

Population: The total population of the county where the firm is headquartered.

Median age: The median age of residents in the county where the firm is headquartered.

Married ratio: The percentage of county residents who are married in the county where the firm is headquartered.

Median income: The median household income of the county where the firm is headquartered.

Male/Female ratio: The ratio of male residents over female residents in the county where the firm is headquartered.

Minority ratio: The percentage of county residents who are nonwhite in the county where the firm is headquartered.

Firm-Level Explanatory Variables

R\&D capital: Five-year cumulative R\&D expenses assuming an annual depreciation rate of $20 \%$.

Sales: Firm sales in millions of dollars.

PPE/EMP: Net property, plant, and equipment per employee in thousands of dollars.

ROA: Ratio of operating income before depreciation to book assets.

Book leverage: Ratio of the sum of short-term debt and long-term debt to book assets.

Sales growth: Log transformation of sales divided by prior year sales.

Tobin's Q: Ratio of market value to book value of assets.

Cash holdings: Ratio of cash to book assets.

Lerner index: Price-cost margin scaled by sales. Calculated as sales less cost of goods sold less general and administrative expenses, all divided by sales.

Total IO: Percentage of shares outstanding held by 13-F institutions.

Analysts: Average number of analysts following the firm over the year.

\section{CEO-Level Explanatory Variables}

Holder 67: Option-based measure of CEO overconfidence. Indicator variable equals 1 for all years after a CEO holds options that are at least $67 \%$ in the money, and 0 otherwise.

Confident: Press-based measure of overconfidence. Indicator variable equals 1 for all years where "confident" press references exceed "cautious" press references.

Tenure: The number of years the CEO was at the helm of the firm.

Delta: Dollar change in CEO stock and option portfolio for a $1 \%$ change in stock price.

Vega: Dollar change in CEO option holdings for a 0.01-unit change in stock return volatility.

\section{References}

Aghion, P.; N. Bloom; R. Blundell; R. Griffith; and P. Howitt. "Competition and Innovation: An Inverted-U Relationship.” Quarterly Journal of Economics, 120 (2005), 701-728.

Aghion, P.; J. Van Reenen; and L. Zingales. "Innovation and Institutional Ownership." American Economic Review, 103 (2013), 277-304.

Alesina, A., and E. La Ferrara. "Who Trusts Others?" Journal of Public Economics, 85 (2002), 207234.

Asker, J.; J. Farre-Mensa; and A. Ljungqvist. "Comparing the Investment Behavior of Public and Private Firms." Working Paper, New York University (2011).

Barberis, N., and M. Huang. "Stocks as Lotteries: The Implications of Probability Weighting for Security Prices." American Economic Review, 98 (2008), 2066-2100. 
Callen, J., and X. Fang. "Religion and Stock Price Crash Risk." Journal of Financial and Quantitative Analysis, forthcoming (2014).

Campbell, C.; M. Gallmeyer; S. Johnson; J. Rutherford; and B. Stanley. "CEO Optimism and Forced Turnover." Journal of Financial Economics, 101 (2011), 695-712.

Chan, L.; J. Lakonishok; and T. Sougiannis. "The Stock Market Valuation of Research and Development Expenditures.” Journal of Finance, 56 (2001), 2431-2456.

Chang, X.; K. Fu; A. Low; and W. Zhang. "Non-Executive Employee Stock Options and Corporate Innovation.” Journal of Financial Economics, forthcoming (2014).

Chang, X.; G. Hilary; J. Kang; and W. Zhang. "Does Accounting Conservatism Impede Corporate Innovation?" Working Paper, INSEAD (2013).

Chava, S.; A. Oettl; A. Subramanian; and K. Subramanian. "Banking Deregulation and Innovation." Journal of Financial Economic, 109 (2013), 759-774.

Chemmanur, T.; E. Loutskina; and X. Tian. "Corporate Venture Capital, Value Creation, and Innovation.” Review of Financial Studies, forthcoming (2014).

Coles, J.; N. Daniel; and L. Naveen. "Managerial Incentives and Risk-Taking." Journal of Financial Economics, 79 (2006), 431-468.

Coval, J., and T. Moskowitz. "Home Bias at Home: Local Equity Preferences in Domestic Portfolios." Journal of Finance, 54 (1999), 2045-2073.

Deshmukh, S.; A. Goel; and K. Howe. "CEO Overconfidence and Dividend Policy." Journal of Financial Intermediation, 22 (2013), 440-463.

Dixit, A., and J. Stiglitz. "Monopolistic Competition and Optimum Product Diversity." American Economic Review, 117 (1977), 297-308.

Domowitz, I.; R. Hubbard; and B. Petersen. "Business Cycles and the Relationship Between Concentration and Price-Cost Margins.” RAND Journal of Economics, 17 (1986), 1-17.

Faleye, O.; T. Kovacs; and A. Venkateswaran. "Do Better-Connected CEOs Innovate More?" Journal of Financial and Quantitative Analysis, forthcoming (2014).

Fama, E. F., and J. D. MacBeth. "Risk, Return, and Equilibrium: Empirical Tests." Journal of Political Economy, 81 (1973), 607-636.

Fang, V.; X. Tian; and S. Tice. "Does Stock Liquidity Enhance or Impede Firm Innovation?” Journal of Finance, forthcoming (2014).

Galasso, A., and T. Simcoe. "CEO Overconfidence and Innovation.” Management Science, 57 (2011), 1469-1484.

Gompers, P.; J. Ishii; and A. Metrick. "Corporate Governance and Equity Prices.” Quarterly Journal of Economics, 118 (2003), 107-155.

Hall, B. "The Financing of Research and Development." Oxford Review of Economic Policy, 18 (2002), 35-51.

Hall, B.; Z. Griliches; and J. Hausman. "Patents and R\&D: Is There a Lag?" International Economic Review, 27 (1986), 265-283.

Hall, B.; A. Jaffe; and M. Trajtenberg. "The NBER Patent Citations Data File: Lessons, Insights and Methodological Tools.” Working Paper, University of California, Berkeley (2001).

Hall, B.; A. Jaffe; and M. Trajtenberg. "Market Value and Market Citations." RAND Journal of Economics, 36 (2005), 16-38.

Hall, B., and R. Ziedonis. "The Patent Paradox Revisited: An Empirical Study of Patenting in the U.S. Semiconductor Industry, 1979-1995.” RAND Journal of Economics, 32 (2001), 101-128.

He, J., and X. Tian. "The Dark Side of Analyst Coverage: The Case of Innovation." Journal of Financial Economics, 109 (2013), 856-878.

Hilary, G., and K. Hui. "Does Religion Matter in Corporate Decision Making in America?" Journal of Financial Economics, 93 (2009), 455-473.

Hirshleifer, D.; A. Low; and S. H. Teoh. "Are Overconfident Managers Better Innovators?" Journal of Finance, 67 (2012), 1457-1498.

Holmstrom, B. "Agency Costs and Innovation.” Journal of Economic Behavior and Organization, 12 (1989), 305-327.

Ivkovic, Z., and S. Weisbenner. "Local Does as Local Is: Information Content of the Geography of Individual Investors' Common Stock Investments.” Journal of Finance, 60 (2004), 267-306.

Kumar, A. "Who Gambles in the Stock Market?" Journal of Finance, 64 (2009), 1889-1933.

Kumar, A.; J. Page; and O. Spalt. "Religious Beliefs, Gambling Attitudes, and Financial Market Outcomes." Journal of Financial Economics, 102 (2011), 671-708.

Lev, B.; B. Sarath; and T. Sougiannis. "R\&D Reporting Biases and Their Consequences." Contemporary Accounting Research, 22 (2005), 977-1026.

Lindenberg, E., and S. Ross. "Tobin's Q Ratio and Industrial Organization.” Journal of Business, 54 (1981), 1-32.

Malmendier, U., and G. Tate. "CEO Overconfidence and Corporate Investment." Journal of Finance, 60 (2005), 2661-2700. 
Malmendier, U., and G. Tate. "Who Makes Acquisitions? CEO Overconfidence and the Market's Reaction.” Journal of Financial Economics, 89 (2008), 20-43.

Manso, G. "Motivating Innovation.” Journal of Finance, 66 (2011), 1823-1860.

Mikesell, J. "State Lottery Sales and Economic Activity." National Tax Journal, 47 (1994), 165-171.

Narayanan, M. "Managerial Incentives for Short-Term Results.” Journal of Finance, 40 (1985), 1469_ 1484.

Pakes, A., and Z. Griliches. "Patents and R\&D at the Firm Level: A First Look." In R\&D, Patents, and Productivity, Z. Griliches, ed. Chicago, IL: University of Chicago Press (1980).

Pirinsky, C., and Q. Wang. "Does Corporate Headquarters Location Matter for Stock Returns?" Journal of Finance, 61 (2006), 1991-2015.

Salop, S. "The Noisy Monopolist: Imperfect Information, Price Dispersion, and Price Discrimination." Review of Economic Studies, 94 (1977), 393-406.

Sapra, H.; A. Subramanian; and K. Subramanian. "Corporate Governance and Innovation: Theory and Evidence." Journal of Financial and Quantitative Analysis, forthcoming (2014).

Schneider, C., and O. Spalt. "Acquisitions as Lotteries: Do Managerial Gambling Attitudes Influence Takeover Decisions?” Working Paper, Tilburg University (2013).

Shu, T.; J. Sulaeman; and P. E. Yeung. "Local Religious Beliefs and Mutual Fund Risk-Taking Behaviors." Management Science, 58 (2012), 1179-1796.

Tian, X., and T. Wang. "Tolerance for Failure and Corporate Innovation.” Review of Financial Studies, 27 (2014), 211-255. 